\title{
"DE CONTRIBUTIONIBUS FISCALIBUS": ELS CONFLICTES ENTRE EL MUNICIPI DE VALLS I LA COMUNITAT DE PREVERES DURANT EL SEGLE XIV'
}

JORDI MORELLÓ I BAGET Institució Milà i Fontanals (CSIC, Barcelona) Qüestions de procediment.- 4. Cloenda.- Apèndix documental.

\section{INTRODUCCIÓ}

Durant la Baixa Edat Mitjana, la pretesa exempció fiscal de l'estament eclesiàstic fou una qüestió plantejada amb relativa freqüència a nivell municipal. D'un lloc a l'altre podem veure repetides situacions similars, consistents a dirimir quin havia de ser el grau de participació dels clergues a les contribucions municipals $\mathrm{i}$ de quina manera havien de participar-hi, ateses les objeccions que aquests solien postular; o, dit a l'inversa, fins a quin punt podien quedar eximits, si del que es tractava era de fer-los co-partíceps, tant com fos possible, de les mateixes obligacions fiscals que tenien els altres ciutadans. Aquesta problemàtica sembla assolir

\footnotetext{
'A la Memòria de la Dra. Regina Sáinz de la Maza Lasoli.

"Anuario de Isstudios Medievales". 29 (1999)
} 
el punt més àlgid a finals del segle XIV, coincidint amb l'augment de les despeses municipals a causa dels donatius a la Corona, les obres de fortificació, etc. Encara que la condició religiosa, amparant-se en disposicions conciliars o d'altra mena, podia ser utilitzada en sí mateixa com a escut per protegir-se de l'assetjament fiscal dels municipis, en la pràctica no tots els clergues podien rebre el mateix tracte, depenent de l'escala social i de la categoria que cada un ocupés dins l'estament eclesiàstic ${ }^{2}$. Certament, la pressió municipal es canalitzà cap a les capes més baixes de l'estament eclesiàstic, a la vegada que fou exercida preferentment sobre les comunitats religioses locals, com eren, doncs, les Comunitats de Preveres. La pugna municipis-clerecia va haver de resoldre's a través de pactes, per mitjà dels quals s'intentaria aconseguir la seva submissió a la fiscalitat municipal, si bé amb una sèrie de condicions o limitacions - tal com veurem en el cas que ens ocuparà-, que serviren al seu torn per conferir als clergues un status fiscal diferent del que tenien els llecs. Ara bé, darrera de totes les qüestions de tipus fiscal que poguessin ser objecte de debat o d'enfrontament, planava un problema de tipus jurisdiccional: ¿tenien els municipis potestat per fer complir les seves disposicions damunt els clergues, en tant que formaven part d'un àmbit jurisdiccional distint del municipal? Tal interrogant apareixà plantejat en el cas del qual anem a parlar ara, a més a més de les qüestions pròpiament fiscals ${ }^{3}$.

\footnotetext{
'De fet, l'alta jerarquia tampoc no va poder sostreure's totalment a les demandes fiscals dels municipis. Podem anotar un cas que es plantejà a la ciutat de Barcelona el 1370 a propòsit d'una reclamació que es féu a l'arquebisbe de Tarragona, per part de dos comissionats dels consellers, Gilabert Sentcliment i Bertran ça-Muntada, per tal que aquell pagués el que li corresponia en les obres dels murs pels béns que tenia dins la dita ciutat ("per rahó de les talles antigues fetes entre los ciutadans e persones ecclesiàstiques poblades o havens rendes, possessions o altres béns dins la dita ciutat, térmens e territori d'aquella"), a la qual cosa respongué el prelat que es meravellava molt que li fessin aquella demanda, "com sia contra dret e llibertat ecclesiàstica"; tot i així, en el cas que hagués de pagar alguna cosa, es mostrava disposat a lliurar els diners "graciosament" i no pas per obligació; Arxiu Històric de l'Arxiprestat de Tarragona, sèrie Registra Negotiorum (1370), c. 3, núm. 6a, fol. 103 v. A propòsit de l'al-ludida "llibertat eclesiàstica", podeu consultar V. FERRO, El Dret Públic Català. Les Institucions a Catalunyal fins al Decret de Nova Planta, Vic, 1987, pp. 25 i 324.

${ }^{3}$ Aquesta qüestió generà una profusa literatura teològica. Sobre això, podeu veure les opinions recollides per un teòleg cinc-centista a J. ALIAGA, Los tributos e impuestos valencianos en el siglo XVI. Su justicia y moralidad según Fr. Miguel Bartolomé Salón, O.S.A. (1539?1621), Roma, 1972, pp. 218 i ss. Certament, el tema que ens ocupa no ha generat una bibliografia gaire profusa, deixant a banda les notícies i referències puntuals que poden aparèixer recollides en moltes monografies locals. Només alguns estudis dediquen algunes planes a aquestes qüestions. Els historiadors francesos són potser els que han prestat més atenció a aquesta problemàtica. Podem citar els treballs de F. HUMBERT, Les finances municipales de Dijon du milieu du XIV siècle à 1477, París, 1961, pp. 73-77; A. HigounET-NaDAL, Les
} 
Ja en un capítol de la nostra tesi doctoral vam parar atenció en els conflictes que es produïren a Valls i a Reus amb les respectives Comunitats de Preveres ${ }^{4}$. En l'actual avinentesa, seria massa llarg exposar els dos casos, de manera que hem optat per un de sol; si hem triat Valls, és pel fet que aporta dades més interessants per copsar les diferents facetes del problema. També aprofitem l'avinentesa, ja que no ho havíem fet abans, per donar a conèixer una sèrie de textos que hem seleccionat d'entre l'important cabal documental que generà el procés judicial en el qual es va veure immersa la universitat d'aquella vila, segons el que figura a l'Apèndix ${ }^{5}$. Tal documentació, en tant que conté aspectes molt de detall sobre la fiscalitat, és d'un

comptes de la taille et les sources de l'histoire démographique de Périgueux au XIV siècle, París, 1963, pp. 52-55; i A. RIGAUDIĖRE, Le financement des fortifications urbaines en France du milieu du XIV siècle à la fin du XV siècle, "Revue historique", 273 (1985), pp. 62-64, on s'exposen diferents exemples locals. La monografia d'A. CASTALDO, Seigneurs, villes et pouvoir royal en Languedoc: le consulat médièval d'Agde (XIII-XIV siècle), París, 1974, dedica moltes planes (de la 289 a la 329) a fer un seguiment dels conflictes sostinguts amb els clergues en aquesta població, encara que s'interessa més pel rerafons polític del problema que no pas per les qüestions de tipus fiscal. Els nombrosos estudis sobre els cadastres de les ciutats italianes aporten alguns referents al problema que ara ens ocupa; per exemple, en el clàssic estudi de D. HERLIHY/CH. KLAPISCH-ZUBER, Les toscans et leurs familles. Un étude du catasto florentin de 1427, París, 1978, p. 151 i ss. Pel cas de Castella, qui ha posat major émfasi en aquests aspectes és D. MENJOT, L'incidence sociale de la fiscalité directe des Trastamares de Castille au XIV siècle, "Historia. Instituciones. Documentos", 5 (1978), pp. 344-351 (remissible al cap. 6 del compendi d'articles del mateix autor: Fiscalidad y sociedad. Los murcianos y el impuesto en la Baja Edad Media, Murcia, 1986). Pel cas mallorquí, podem citar el treball de J.F. LóPEZ BONET, La pràctica fiscal a la baixa edat mitjana, "Randa", 29 (1991), espec. pp. 33-34. Algunes qüestions relatives a aquest tema han estat objecte d'un primer plantejament per part de M. TURULL, El impuesto directo en los municipios catalanes medievales, dins Finanzas y fiscalidad municipal. ("V Congreso de Estudios Medievales"). León, 1997, pp. 75-133, amb diverses remissions bibliogràtiques.

${ }^{4} \mathrm{Cf}$. J. Morelló, Fiscalitat i finances de dues viles del Camp de Tarragona: Reus $i$ Valls durant els segles XIV $i$ XV, 2 vols., Tesi doctoral inèdita, Univ. de Barcelona, 1998, p. 596 i ss. (cap. VI). Una i altra localitat ofereixen situacions gairebé paral-leles, així pel que fa a la cronologia del conflicte com també a nivell de les qüestions plantejades al llarg del mateix.

5A la sèrie Cort del Batlle del Fons judicial de l'Arxiu de Valls s'han conservat tres volums relacionats amb aquest procés judicial: el més voluminós (el que porta la signatura topogràfica 1.2.48) conté abundant informació respecte de totes les gestions realitzades per la universitat davant els advocats i els jutges que intervingueren en la causa, inclosa la correspondència amb altres viles, i la recopilació d'abundant informació que havia de servir com a suport a les tesis defensades pels representants municipals, que abasta fins al final del volum, on apareix copiada la sentència arbitral dictada el 1392. En el segon volum (sig. top. 1.2.51) es copià aquesta mateixa sentència, així com la del 1395, que posà fi al plet. El tercer volum (sig. top. 1.2.52) conté únicament els nomenaments de síndics $\mathrm{i}$ procuradors realitzats el 1391 , tant per la universitat com per la Comunitat de Preveres. Part de les sentències produïdes en aquest procés apareixen recollides en el fons de pergamins de l'arxiu local amb la numeració que indicarem en cada cas. Les referències documentals no s'acaben aquí, però ara per ara hem hagut de limitar la nostra exposició a les qüestions claus en base als principals documents produitts en aquest procés. 
interès que ultrapassa la problemàtica que més directament afectava els clergues, ja que, a través seu, podem conèixer millor el funcionament de la fiscalitat que es practicava a nivell local ${ }^{6}$.

\section{LES FASES DEL CONFLICTE}

Abans de res, hem d'informar al lector del context local del qual anem a parlar. A Valls, com segurament a la majoria de poblacions del seu rang (comptabilitza 569 i 400 focs, segons els dos fogatjaments més representatius de la segona meitat del s.XIV), hi havia una Comunitat de Preveres, la qual estava formada per una quinzena de capellans, a més del rector $^{7}$. Tanmateix, la població eclesiàstica de Valls no quedava reduïda a aquesta comunitat. El desenvolupament demogràfic i econòmic que la vila arrossegava del segle XIII convertí Valls en un centre pròsper, que degué propiciar el fet que alguns ordes religiosos l'escollissin per a fundar-hi els seus convents. Ja abans de mitjan segle XIV trobem instal-lades dues comunitats conventuals: la del Carme ${ }^{8}$ i la de Sant Antoni ${ }^{9}$. Fet i fet, el

\footnotetext{
${ }^{6}$ Fins al punt que molts aspectes de caràcter normatiu els coneixem a través d'aquesta documentació de tipus judicial, on, com es posarà de relleu en el present treball, sairegen moltíssimes qüestions que els preveres consideraven dubtoses, mitjançant l'exposició d'una casuística molt àmplia $\mathrm{i}$ variada.

${ }^{7}$ Es desconeix, però, la data de la seva fundació. El nombre de quinze es manté abans i després de la Pesta Negra. En els documents que figuren a l'Apèndix, només el de 1342 cita els noms de tots els preveres: un total de 15. D'aquests, 7 són indicats com a preveres beneficiats a l'església major de Sant Joan, mentre que els 8 restants figuren tan sols com a preveres que servien a la mateixa església $i$, per consegüent, sense estar en possessió de cap benefici. Això seria una diferència respecte del període posterior, quan ja tots els preveres de la Comunitat tenien cura d'algun benefici. D'altra banda, i malgrat fer aquella distinció, sembla fora de dubte que tots quinze residien a Valls. El 1391 el nombre de components de la Comunitat continuava sent de quinze, aquest cop considerats tots ells com a beneficiats; així figura en el nomenament dels seus procuradors per intervenir en el procés que ara ens ocupa; Arxiu Històric Comarcal de Valls, Fons judicial, sèrie Cort del batlle (sig. top. 1.2.52), fols. 6 r. -14 v.

${ }^{8}$ La comunitat de carmelites, instal-lada a Valls d'ençà el 1321 , estaria formada per una dotzena de frares. La pròpia universitat gestionà l'establiment d'aquesta comunitat comprometent-se a donar al prior provincial del dit orde una suma de $10.000 \mathrm{~s}$. per a la construcció de l'església, a més d'adquirir el terreny que havia de servir d'emplaçament al convent, situat extramurs, amb tots els seus annexes; AHAT, Manuals de Valls, caixa 2, n." 14 , fol. $45 \mathrm{v}$. S'ha dit que els carmelites escolliren Valls com a base operacional per tal de combatre la heretgia càtara que s'escampà per les Muntanyes de Prades; cf. E. GoRT, Història de Cornudella de Montsant: Una vila del Comtat de Prades, Reus, 1994, p. 87.
} 
nombre de clergues residents a Valls (entre seglars i regulars) es podria situar d'ençà aleshores en un mínim de vint-i-cinc ${ }^{10}$. Aquesta xifra implicaria un baix percentatge en relació amb la població laica de la vila: entre un $3-4 \%$, si prenem de referent un còmput de focs realitzat entre les localitats del Camp el 1339 (anterior, doncs, a la Pesta Negra), i, entre un 5-6\%, en relació amb el fogatge de 1378 .

Fora dels preveres, també es produïren alguns conflictes per raons fiscals amb els altres grups de religiosos residents a la vila, encara que l'únic que en sabem es redueix a moments molt puntuals" ${ }^{\prime \prime}$. Altres conflictes (relacionats amb el monestir de Poblet per la ubicació d'una granja dins el terme de Valls) són de caire més jurisdiccional o territorial, malgrat incloure també qüestions fiscals ${ }^{12}$. Aquí parlarem únicament de la Comunitat de

${ }^{9}$ Establerts (segons G. SECALL, La medicina i els antics hospitals de Valls, Valls, 1908, p. 47), des de finals del s.XIII, tenien al seu càrrec la gestió d'un hospital. Com és sabut, aquest orde tenia cura dels malalts d'ergotisme (a l'època, l'anomenat "foc de sant Antón"). Ignorem quantes persones formarien part d'aquesta congregació o si realment arribà mai a constituir-se com a tal congregació; l'única persona de la dita casa de Sant Antoni que tenim registrada documentalment és el seu comanador. Cal suposar, però, que aquest administraria la casa amb l'ajuda de personal auxiliar.

${ }^{10}$ Pels volts del 1366 s'erigí l'ermita de Santa Maria del Lledó (o dels Miracles) que uns anys després passà a mans de l'orde del Sant Sepulcre per donació que en féu la universitat; segons apuntava F. PUIGJANER, Historia de la villa de Valls desde su fundación hasta muestros días, Valls, 1881, p. 87. Per tenir cura d'aquesta ermita o capella es deuria designar alguna persona, que potser no necessàriament seria de condició religiosa.

"El cas que tot seguit exposem se situa, de fet, al marge del municipi. El 1354 s'obligava al convent del Carme a pagar a compte de les imposicions reials a un arrendatari de Tarragona. Però, davant la negativa manifestada pel prior del convent, l'Oficial de l'arquebisbe ordenà als batlles de Valls que fessin una crida pública per tal que cap emfiteuta pagués els censos que havia de satisfer al dit convent; AHAT, Manuals (Valls), c. 8, núm. 38, fol. 20 r. Tals imposicions, dites "reials" per diferenciar-les de les que eren arrendades per la vila per la mateixa època, foren gestionades al marge dels municipis d'acord amb l'estipulat a les corts de Perpinyà de 1351. El fet obre més interrogants que respostes, ja que, si els frares d'aquest convent havien de contribuir a les imposicions reials, què succeïa amb les que gestionava la vila"? Desconeixem, per altra banda, si mai s'arribà a fer cap acord entre el dit convent i la universitat sobre contribucions fiscals. En un altre percanç d'índole fiscal que es produí a principis ja del s.XV trobem involucrat el comanador de Sant Antoni, el qual refusava contribuir en una talla per un censal que havia comprat de feia poc; AHCV, Clavaria, 1401/02, fol. 34 r.

${ }^{12}$ Des d'una altra perspectiva, cal referir-se als conflictes que es produïren a finals del s.XIV (coetàniament al cas que ara ens ocuparà) entre la universitat de Valls i la granja de Doldellops, que pertanyia al monestir de Poblet, tot $\mathrm{i}$ formar part del terme de la vila, tal com es dictaminà el 1395; aquest plet ha estat estudiat per J. Rius, Un plet baix medieval entre el monestir de Poblet i la vila de Valls: la granja de Doldellops, dins Miscel-lània en homenatge al P. Agustí Altisent, Tarragona, 1991, pp. 589-603. Hom feia constar que ni Poblet ni els seus majorals havien de contribuir per res del que tenien dins el territori de la granja ni, en general, dins el terme de Valls. Aquest cas és més típic, però, dels conflictes sostinguts amb els grups de 
Preveres, tocant a la qual podem fer un seguiment cronològic bastant exhaustiu, gràcies, doncs, al considerable cabal d'informació que generà aquest conflicte a nivell local.

La conflictivitat entre la universitat de Valls i la dita Comunitat s'inicia a la dècada de 1340. Concretament, el 2-I-1342 s'establia un pacte (amb la intervenció d'algunes persones notables, els noms de les quals no tenim especificades) que serví per fixar les obligacions fiscals que haurien de ser assumides pels preveres a partir d'aquell moment [doc. núm 1]. L'època no és gens fortuïta, ja que coincideix amb el despertar, per dir-ho així, de la fiscalitat municipal. Ignorem, però, quins debats precediren l'establiment d'aquest pacte, el primer segons sembla, ja que no tenim notícia de cap altra que l'hagués precedit ${ }^{13}$. Tret d'això, esdevé problemàtic saber durant quant de temps varen tenir vigència les disposicions contingudes en aquest pacte o si tals disposicions varen ser objecte d'un escrupulós compliment. A posteriori, tenim constància de moments de fricció entre la universitat i els preveres; per exemple, el 1369. Coincidint amb la reforma de les fortificacions que la vila començà a endegar precisament aquest any, alguns preveres refusaren contribuir a les talles que la universitat destinava a sufragar les despeses d'aquelles obres ${ }^{14}$. Però, el problema, pel que es veu, era de major abast, ja que també refusaven contribuir a les qüèsties (talles ordinàries) ${ }^{15}$. A partir de la dècada de 1370 , les relacions entre la universitat i la Comunitat de Preveres serien cada cop més tibants, fins al punt que tot l'estipulat en l'anterior pacte deuria quedar en lletra morta ${ }^{16}$.

terratinents amb possessions ubicades dins els termes municipals, que també hem estudiat a la nostra tesi pel cas de Reus i de Valls; J. MoRElló, Fiscalitat i finances..., pp. 387-93.

${ }^{13}$ Piñas, en una relació sumària que fa del conflicte entre la universitat i els preveres al-ludeix, sense esmentar la font, a dues sentències arbitrals, una donada per l'arquebisbe Ximèn de Luna el 1319 per la qual els preveres restaven obligats a avaluar els seus béns de cara a les contribucions municipals, i una altra més tardana, del 7-VI-1390, en la qual se'ls obligaria a contribuir pels seus béns patrimonials; cf. J. PIÑAS, Bosqueigs històrics sobre l'agricultura vallenca, dins "Monografies vallenques", Valls, 1967, p. 128. Això no obstant, en les recerques que hem realitzat, no hem localitzat cap de les dues sentències al-ludides per aquest autor.

${ }^{14}$ Per aquesta raó havien estat taxats "iuxta suas facultates"; AHAT, RN (1369), c. 2, núm. $4 d$, fol. 2 r. $-v$.

${ }^{15} \mathrm{AHCV}$, Clavaria, 1371 , fol. $19 \mathrm{r}$.

${ }^{16} \mathrm{Ja}$ és significatiu que els preveres no apareguin registrats a les estimes del 1378, les primeres que es conserven en aquesta localitat. En elles tan sols s'anota "la dona del comanador" (de Sant Antoni), que segurament seria una serventa que estava al seu càrrec. En canvi, aquest comanador apareix registrat a les posteriors estimes de 1397 (fol. 195 r.-v.) i de 
Ja a finals del segle XIV, s'encetà el procés judicial que donà peu a la promulgació de vàries sentències. El 1392 es procedí al nomenament de tres àrbitres perquè donessin el seu dictamen sobre una sèrie de qüestions que eren motiu de discòrdia entre la universitat i els preveres [doc. núm 2]. Si, d'una banda, es replantejaven qüestions sobre les quals ja s'havia fet un pronunciament cinquanta anys abans (a propòsit del pacte al·ludit), en aquest moment s'introduïren noves qüestions fiscals que alhora són reflex de l'important transformació que havia experimentat la fiscalitat municipal des de mitjan segle XIV. A més de les qüestions que comentarem més endavant, en aquesta sentència arbitral es donen a conèixer una sèrie de mútues reclamacions: la universitat reclamava als preveres 20.000 florins, que era el total calculat per les despeses fetes fins aquell moment en tot tipus d'obres (murs, valls, esglésies, camins, ponts... $)^{17}$. Per la seva part, els preveres també reclamaven a la universitat vàries sumes de diners per diverses raons: 60.000 sous per les imposicions que els preveres havien hagut de pagar en la compra d'alguns queviures (pa i vi); $66.300 \mathrm{~s}$. per vendre vi sense la corresponent imposició; i $100.000 \mathrm{~s}$. per les possessions (albergs, horts i altres possessions situades prop de la muralla) que la vila havia fet derruir per mor de les fortificacions ${ }^{18}$. Això no obstant, es preveia que, si en l'avenir, la universitat indemnitzava els habitants de la vila, hom estaria obligat a fer-ho per igual als preveres pels béns i rédits afectats ${ }^{19}$. Davant totes aquestes reclamacions, els àrbitres prengueren potser la decisió més sàvia que podien prendre, és a dir, imposant callament perpetu a totes dues

1402 (fol. 54 r.-v.), almenys per alguns béns.

${ }^{17} \mathrm{~A}$ propòsit d'això, es redactà un llibre on. any per any, figuren totes les despeses d'aquell tipus (o encara d'altres relacionades) que els jurats i clavaris de la vila varen fer des de mitjan segle XIV fins al moment actual: AHCV, Cort del Batlle (1.2.48.), fols. 44 r. -57 r.

${ }^{18}$ Això ens portaria a la dècada de 1370 , quan s'inicià la reforma de les fortificacions. D'aquesta època, justament, ens consta que els frares del convent del Carme formularen diverses queixes a la universitat, en un cas reclamant de ser indemnitzats també pels censos que rebien sobre alguns edificis que havien estat destruïts per bastir l'obra dels murs; AHCV, Clavaria, $1377 / 78$, fol. 73 r.-v.

${ }^{19}$ Els dirigents de la vila varen trametre correus a d'altres viles, com Vilafranca del Penedès, en aquest cas per saber si la Comunitat de Preveres d'aquest lloc havia estat indemnitzada per les propietats derruïdes a propòsit també de les obres de fortificació; AHCV. Cort del batlle (1.2.48), fol. $114 \mathrm{v}$. Per aquesta raó, també s'inicià un inventari de les propietats dels preveres afectats; ibidem, fol. $134 \mathrm{v}$. i ss. 
parts $^{20}$. No obstant això, aquesta sentència no deixà massa contents els preveres, que a partir d'aleshores varen fer tot el possible per torpedejar les resolucions dictades pels tres àrbitres. En efecte, al cap de poc temps presentaven diversos dubtes (numerats fins a nou), en algun cas sobre qüestions molt puntimirades [els extractes d'aquesta requesta els hem inclós al peu de nota del doc. núm 3]. En canvi, la posició dels jurats de la vila era ben bé una altra, en entendre que calia respectar i acatar la sentència donada anteriorment. Tot i així, els preveres continuaren insistint en les seves reclamacions: el 1394 presentaren una autèntica bateria d'al-legacions, ampliant els anteriors dubtes fins a un total de setze [doc. núm 3]. L'afer trascendí a l'Oficialat de Tarragona: el 20 de juny d'aquell mateix any, Pere de Cases, oficial de l'arquebisbe, nomenat jutge pel mateix prelat, emitia una declaració, per bé que referida únicament a una qüestió nova que s'havia plantejat a propòsit de l'onzè establert per la universitat aquell mateix any ${ }^{21}$. Finalment, el 30-IV-1395, el jutge d'apel-lacions de Tarragona, micer Andreu Terre, dictava sentència sobre totes les qüestions pendents de resolució [doc. núm 4]. Podem dir que aquesta última declaració judicial posà fi al conflicte, encara que aquest seguiria cuetejant durant alguns anys més per culpa dels preveres, o d'alguns d'ells, que continuaren manifestant la seva disconformitat. Però, pel que sabem, durant el segle $X V$, ja no calgué recórrer als tribunals per arranjar les diferències.

Encara que el més important serà conèixer la solució final que es donà a la darrera sentència indicada, també és important saber quina fou l'evolució dels problemes plantejats en el decurs de la cinquantena d'anys que podem atènyer i els canvis introduits a tenor de l'establert a través de les declaracions i sentències que la precediren, començant per la de 1342, seguint per la del 1392 i finalitzant, doncs, amb la del 1395, sense passar tampoc per alt les diferents al legacions interposades pels preveres, que tenen tant 0 més interès que les pròpies sentències.

\footnotetext{
${ }^{20} E l$ fet és que cap d'aquestes qüestions torna a postular-se en la subsegüent etapa del procés judicial. Fixem-nos, d'altra banda, que les quantitats mútuament reclamades són, per la banda de la universitat, $220.000 \mathrm{~s}$., i, per la banda dels preveres, $232.300 \mathrm{~s}$, amb una diferència no molt important. Vist així, sembla prou encertada la decisió presa pels àrbitres.

${ }^{21}$ Tal declaració apareix inserida enmig de molts altres actes realitzats en aquest procés a AHCV, Pergamins, n. ${ }^{\circ} 203$ (amb dates extremes que van des del 20-I-1394 fins al 30-IV-1395, en què es dictà la sentència final, inclosa també en aquest document).
} 


\section{QÜESTIONS EN LITIGI}

Com ja hem deixat entreveure fins aquí, són diverses les qüestions que es varen anar plantejant en les diferents etapes del conflicte. D'antuvi, cal fer la següent advertència: la majoria d'aquestes qüestions pertanyen a l'àmbit de la fiscalitat directa, així pel que fa a les talles en la seva doble vessant (de caràcter ordinari o extraordinari ${ }^{22}$ ) com als onzens. La fiscalitat indirecta pràcticament es deixa de racó, fet que tindria una simple explicació: tal com es pot desprendre del pacte establert el 1342, els preveres no havien de contribuir a les imposicions ${ }^{23}$. Ja de bon començament, doncs, aquesta exempció, que seria total, atorga a la fiscalitat directa el màxim protagonisme en els posteriors debats sostinguts entre les dues parts litigants. Això constitueix un tret característic que, per exemple, no s'observa en altres localitats, especialment en àmbits urbans, on les imposicions varen constituir el principal cavall de batalla ${ }^{24}$. No obstant això, a la sentència del 1392 s'escolava una interessant qüestió a propòsit de la imposició del vi que els preveres venien als laics ${ }^{25}$. Els restants problemes plantejats ens remeten a

\footnotetext{
${ }^{22}$ Fem avinent que a Valls es començaren a establir talles anualment a partir del 1369 a fi de coadjuvar, juntament amb el producte de les imposicions, al sosteniment de la despesa. fet que no desbancà l'establiment d'altres talles destinades a motius més concrets. En tot cas, la dinàmica $\mathrm{i}$ forma de percepció era diferent en unes $\mathrm{i}$ altres talles; àdhuc en les diferències de nom, ja que el terme "qüèstia" sol reservar-se per a les talles ordinàries. Tocant al règim fïscal establert el 1369, ens remetem al nostre article: J. MORELLó, El règim municipal de Valls segons unes ordinacions de 1369, "Historia et documenta", 1 (1994), pp. 11-39.

${ }^{23}$ Fins al punt que un motiu d'exempció dels preveres era no haver de contribuir en el cas que es decidis satisfer les "qüèsties" a través d’imposicions (i no a través, doncs, de talles). En aquest punt, hom fa referència a una "ordinationem impositionis" de la qual desconeixem la data i el contingut, però en virtut de la qual es deuria regular la contribució dels preveres -o millor dir la seva exempció- en el pagament de les imposicions.

${ }^{2+} \mathrm{A}$ Tarragona, una de les qüestions que provocà més enfrontaments entre la universitat $i$ la clerecia fou la negativa d'aquesta a contribuir pel vi que introduïen a la ciutat; cf. F CORTIELla. Una ciutat catalana a darreries de la baixa edat mitjana: Tarragona. Tarragona, 1984. p. 186. Segons una concordia establerta el 1415. els clergues foren autoritzats a entrar vi per a vendre durant la temporada coneguda com a "mesa del vi", però a canvi de satister les mateixes imposicions que els llecs. Això fou acceptat pels clergues a canvi d'importants contraprestacions: cf. F. CORTIELLA. La producció vinícola a la ciutat de Tarragona al segle $X V$. dins Jornades sobre la viticultura de la Conca Mediterrìnia, 1986, Tarragona, 1995. pp. 574-77.

${ }^{25}$ La qüestió girava al voltant de si tals vendes de vi s'havien de fer amb o sense la taxa corresponent, que en aquell moment era de 5 sous per somada de càrrega. Tot remarcant que la imposició només l'havien de pagar els compradors, es condemnà els preveres a vendre el seu vi amb la imposició afegida, puix que la taxa es descomptaria de la mesura. Fins aleshores, pel que sembla, els preveres no havien establert cap pacte amb la universitat sobre aquesta qüestio que, de fet. ja no torna a aparèixer en les posteriors declaracions judicials. Interpretem. doncs,
} 
les talles, com succeeix des del principi, o bé als onzens, d'ençà llur aparició a Valls a la darrera dècada del segle XIV ${ }^{26}$.

Perquè l'exposició sigui més clara i entenedora, hem optat per fer una dissecció de la problemàtica en tres punts principals: a) motius de contribució; b) béns imposables i mode de contribució; i, c) qüestions de procediment. A partir dels textos de l'Apèndix, hom podrà fer-se una idea més al detall de la complexa casuística que es va anar establint (potser no gaire més complexa, però, de la que afectava la població laica) en la regulació de les obligacions fiscals d'aquest col·lectiu:

\section{a) Motius de contribució}

La participació dels preveres a les talles establertes pel municipi tendí a circumscriure's únicament a determinats casos, és a dir, a talles destinades a cobrir unes necessitats molt concretes. Ara bé, segons la sentència del 1342, els preveres havien de contribuir en totes les talles 0 qüèsties que es fessin per qualsevol quantitat, àdhuc si es pagaven a través de malles ${ }^{27}$; l'única salvetat que s'anotava en aquest moment concernia les talles que estiguessin motivades per causes criminals, segurament en l'intent de preservar el diferent for reconegut als eclesiàstics. El 1392 s'acotaren molt més els motius de contribució, establint que només haurien de contribuir per les talles destinades a les obres d'esglésies (o també per la fabricació de campanes, obres pies...) i per actuacions en infrastructures viàries (ponts, carrers, camins), a la qual cosa s'afegien salaris de vinyògols $i$ de metges ${ }^{28}$; $i$, finalment, en les obres de murs i valls, de la qual cosa

que el problema quedà resolt amb la sobredita disposició.

${ }^{26} \mathrm{~A}$ Valls, la primera vegada en què es decidí l'establiment d'onzens fou el 1394; sobre això, vegeu J. MORELLó, La problemática d'un impost a finals del segle XIV: la imposició de l'onzè a Valls el 1394, "Miscel-lània de Textos Medievals", 8 (1996), pp. 249-82. I. de fet. les primeres referències a aquest impost en el conflicte que ens ocupa apareixen aquell mateix any. constituïnt un exemple més de la sincronia que es dóna entre certs conflictes i determinades novetats fiscals.

${ }^{27}$ per obolos seu medallas, diu el text. Amb aquests termes, hom feia referèncial a un tipus de talla de periodicitat setmanal basada en el lliurament de petites quantitats o de quantitats fraccionades.

${ }^{28}$ Tals són, precisament, les despeses que figuren anotades en el registre que hem indicat més amunt (nota 17). L'obligació de contribuir per coses de profit mutu apareix indicada, igualment, en una concòrdia establerta el 1354 a la Selva; vegeu J. PIÉ, Annals inèdits de la vila de la Selía del Camp de Tarragona, Tarragona, 1984, p. 211. 
només quedaven eximits del tram del Carme, potser perquè el finançament d'aquest tram aniria a càrrec dels frares del convent carmelita. De cara a les talles establertes per altres raons (com els donatius a la Corona, fogatges, etc.), cal suposar que n'estarien totalment exempts.

A nivell més general, la qüestió principal era obligar els preveres a contribuir per despeses que tinguessin una utilitat comuna (o veïnals, si preferiu), exclosa qualsevol altra raó que no tingués tal consideracióo ${ }^{29}$. El principi "res comunis comuniter omnes tangens, ab omnibus debet aprobari" el trobem expressat a propòsit de la reclamació feta per la universitat als preveres el $1369^{30}$. La defensa de la vila, per exemple, era una qüestió que concernia tots els qui gaudien de la protecció que oferien les muralles ${ }^{31}$. Com a talles d'utilitat comuna podien ser incloses, doncs, totes les destinades a sufragar les obres públiques ja indicades, tant si es referien a les obres de murs i valls, com d'altra mena (ponts, camins...), incloent-hi, així mateix, les retribucions dels abans al-ludits (vinyògols $\mathrm{i}$ metges), que també garantien la prestació de serveis de tipus comunitari, i dels quals es beneficiaven tant els laics com els clergues. Altrament, per als representants municipals era inconcebible que els preveres no volguessin prestar el seu ajut a les talles que es feien per a la conservació o millora de les esglésies,

\footnotetext{
${ }^{29} L$ ater venia de lluny. Segons sengles disposicions donades en el tercer i quart Concili de Letrán (de 1179 i 1215, respectivament), l'Església acceptava de participar en una contribució voluntària quan es justifiqués pel bé comú: cf. M. TURULL, El impuesto directo cit., p. 99, n. 80.

${ }^{30}$ Aquesta màxima de dret era invocada sovint, almenys d'ençà el s.XIII, encara que dins un context conceptual molt més ampli que el fiscal. Com diu cert historiador, "on reconnaissait donc, au début du XIII s., que certaines mesures onéreuses devaient être acceptées, et éventuellement discutées, par tous ceux qu'elles pouvaient toucher ou par leurs représentants qualifiés. Cependant, dans ce cadre général, le principe Quod ommes tangit devait trouver une application particulièrement abondante et comme un terrain d'élection, en matière de taxation. Et ceci. d'abord, dans le monde ecclésiastique"; of. Y. CONGAR, Quod ommes tangit, ab) ommibus tractari et approbari debet. "Revue historique de droit français et étranger", 36 (1958). pp. 210-259 (reprint a İDEM. Droit ancien et structures ecclésiales. London: Variorum Reprints. 1982).

${ }^{31}$ En altres llocs, davant el mateix problema. s'obligava als clergues a contribuir. Com a Manresa, segons es recull en una disposició donada per l'infant Joan el 1369: cf. M. TORRAS (ed.), El Llibre Verd de Manresa (1218-1902), pp. 253-54, citat per M. TURULL. El impuesto directo cit.. p. 99. A Tarragona, larquebisbe es pronuncià favorable el 1430 a què la clerecia de la ciutat participés en el pagament de les despeses que ocasionaven les obres de les muralles; cf. F. CORTIELla, Una ciutat, cit., p. 282. La lluita per obligar els clergues a contribuir a les despeses de fortificació fou el principal cavall de batalla que es plantejà a les ciutats franceses: cf. A. RigAudiĖRE, Le financement des fortifications cit., pp. 62-64.
} 
perquè tals despeses, com declararen els jurats vallencs, eren més de la incumbència dels clergues que no pas dels laics! ${ }^{32}$.

Tot això només tenia validesa sempre que tals despeses servissin realment per satisfer aquelles despeses i no altres. En aquest punt, la desconfiança dels preveres envers els dirigents municipals podia ser bastant justificada perquè, amb l'excusa de donar satisfacció a despeses en les quals s'havia de fer participar aquell col-lectiu, es podia acabar desviant el producte de la recaptació a d'altres finalitats, fora de l'àmbit de subjecció fiscal dels preveres. El 1394, per exemple, aquests recelaven d'una talla que la universitat havia establert per a l'obra de l'església [doc. núm 3, punt 14 è] ${ }^{33}$. La resposta donada aquell mateix any, per part del jutge d'apel·lacions, fou prou clara, en el sentit que hom hi estava obligat sempre que una i altra cosa es destinés a la referida obra. Quelcom semblant es plantejà amb l'onzè: segons la sentència donada per l'Oficial de Tarragona el 26-VI-1394, els preveres no haurien de pagar íntegrament aquest impost, sinó de forma proporcional als béns pels quals eren obligats a les altres contribucions municipals, $i$, només per aquella quantitat que la universitat destinés a sufragar les càrregues en les quals estaven obligats per l'anterior sentènci$\mathrm{a}^{34}$. Vist així, no hi havia inconvenient perquè els preveres contribuïssin en l'onzè de la mateixa forma que tenien estipulat a propòsit de les talles. Ara bé, parlem d'un impost que el municipi solia destinar al pagament dels seus deutes i a l'amortizació de censals ${ }^{35}$. El curiós és que cap d'aquests motius

\footnotetext{
${ }^{32}$ Considerant, doncs, que es tractava de càrregues merament eclesiàstiques, ja que es feien per a utilitat de l'Església; AHCV. Pergamins, núm. 193. Tal declaració figura en la resposta donada pels jurats a les reclamacions dels preveres el $20-\mathrm{V}-1392$

${ }^{33}$ Aquesta talla fou taxada a raó d'1 diner per lliura $(0.416 \%)$, però afegint-hi $4 \mathrm{~s}$. de "sobre mesa", segons s'indica.

${ }^{34}$ Tal declaració fou ratificada posteriorment per micer Andreu Terré; AHCV. Pergamins, núm. 203. Hom considerava que aquella declaració o sentència era definitiva. En això es donava la raó a la universitat i es condemnava els preveres a pagar les despeses ocasionades per totes les al-legacions que havien interposat en aquesta qüestió.

${ }^{35} \mathrm{Com}$ es declarava el 5-II-1394, la universitat imposà aquest onzè per redimir censals, el qual havia de gravar totes les col-lectes $\mathrm{i}$ guanys de censals. Davant el refús dels preveres a contribuir-hi. els representants municipals postulaven que hi estaven obligats, tant pels béns patrimonials com pels aniversaris i també per les rendes dels beneficis; AHCV. Pergamins, núm. 203. Segons el parer dels representants municipals, els preveres havien de contribuir a les càrregues de la universitat, entés això en sentit molt ampli: "cum ipsa onera quedam veniant pro muris, quedam pro ornamentis ecclesie et oneribus eiusdem, quedam pro aliis necessitatibus universitatis ad que tenentur bona que possident clerici". D'acord amb aquest argument, els preveres també estaven obligats a contribuir en aquell onzè. El que es plantejava seria la impossibilitat de destriar la recaptació d'un impost en funció de les múltiples despeses a les
} 
figura en les obligacions tributàries estipulades amb els preveres, almenys per tot el que es refereix a les talles. Sigui com sigui, amb l'onzè s'afegia un motiu més per obligar els clergues a contribuir, és a dir, sempre que es tractés de solventar el deute municipal, la qual cosa semblaria deixar un major marge de maniobra a l'hora d'ampliar les obligacions tributàries dels preveres pel que fa, doncs, als motius de contribución ${ }^{36}$.

\section{b) Béns imposables $i$ mode de contribució}

Anem a veure ara per quins béns pertanyents als preveres podien ser sotmesos a les contribucions municipals (i la forma de taxar-los) i, a l'inversa, quins béns podien ser eximits de contribució. Una i altra cosa fou objecte de regulació a través de les successives declaracions realitzades al llarg del segle XIV. Es tracta de l'afer que més complexitat presenta en funció de les múltiples variables que es tenen en compte. Tot plegat, fa la impressió que la fiscalitat aplicada als preveres era més complexa que la que afectava a la població en general, llevat potser dels vilatans que gaudien d'algun tipus de franquesa, d'on es derivava també un règim fiscal especial. Com veurem, hom fa distinció entre els béns considerats propis i els d'església, és a dir, establint una separació taxativa en funció de la titularitat d'aquests béns. Una altra qüestió concernia la naturalesa dels béns que havien de ser sotmesos a contribució: el moble? l'immoble? els semovents? A nivell més concret, n'hi havia (en l'àmbit de les rendes) que podien ser objecte d'un debat més intens: especialment, quan es parla dels censals assignats als beneficis dels quals els preveres tenien cura o pel que fa també als que eren assignats a la celebració d'aniversaris ${ }^{37}$.

Segons la primera sentència (la del 1342), els preveres havien de contribuir a les talles per tots els seus béns seients (inclosos "censals"),

quals podia anar destinat, cosa que no era tingut en compte a les diferents sentències promulgades en el conflicte que ens ocupa. Tot plegat, semblaria donar a entendre que l'onzè no sempre seria destinat a la finalitat que tenia comesa.

"Així es comprova pel cas també de Cervera, segons l'exposat per M. Turull. El impuesto directo cit., p. 100.

${ }^{37}$ Això últim no sols incumbia els preveres sinó també les persones laiques que es beneficiaven d'aquestes rendes $\mathrm{i}$ que en certa manera també estarien afectades per algunes de les resolucions donades a les sentències que anem a comentar tot seguit. 
independentment de com haguessin anat a parar a les seves mans ${ }^{38}$. En aquest cas, s'imposaria la mateixa taxa de contribució que s'aplicava als laics, raó per la qual aquesta ja ni tan sols s'indica. En canvi, en el cas dels béns mobles, es contribuïa de forma diferent als laics. Per als preveres es fixava una taxa proporcional de 2 sous per milanar (o sia, d'un $0,2 \%$ ). De tal contribució tan sols quedaven eximits alguns béns, com direm més endavant. Així mateix, també els censals dels aniversaris eren objecte d'un tracte especial, en ser sotmesos a una taxa molt més gravosa de 50 sous de cada mil, o sigui, ni més ni menys del $5 \%{ }^{39}$. Sembla, doncs, que hi havia un major interès per gravar especialment la possessió d'aquest tipus de béns que no pas d'altres. Tot això comportava realitzar una valoració de béns segons els procediments que comentarem més endavant.

El 1392, quan la contribució dels preveres pràcticament s'havia restringit a les talles destinades a obres públiques i d'església, es fixaren alguns límits respecte del tipus de béns que podien ser gravats en cada cas. Així, en les talles d'església o similars, havien de contribuir -igual que els laics- en tot tipus de béns, tant propis com d'església, i així també pels beneficis i aniversaris. En el cas de les talles realitzades per obres de ponts etc., llur contribució es limitava als béns propis patrimonials (immobles o rédits), deixant fora de contribució els béns d'església (beneficis i aniversaris) $\mathrm{i}$ els béns propis de caràcter moble o semovent, segons sembla desprendre's del que es declara a la sentència. La mateixa disposició, però, s'aplicava a les talles d'obres de murs. Aquest cop no s'indica cap tipus de gravamen, que potser seria idèntic al dels laics, almenys en els pocs casos en què estaven obligats a participar al sosteniment de les despeses municipals. Així, doncs, el règim fiscal dels preveres quedava molt circumscrit a uns casos molt puntuals. Llur exoneració requeia més que res sobre els seus

\footnotetext{
${ }^{38}$ Una qüestió que no veiem reflectida en el cas que ens ocupa, i que sembla ser força corrent en els conflictes desenvolupats en altres llocs, és aquella que fa referència a l'origen dels béns traspassats; així, si un prevere adquiria béns de llecs que ja contribuïen, hauria de seguir contribuïnt per aquest bé, en tant que es faria prevaler l'anterior condició. És possible que tal supòsit no fos motiu de discussió en tant que ja devia estar clarificat a partir d'altres disposicions. En canvi, és una qüestió que trobem contemplada en els conflictes que la universitat de Valls sostingué amb els homes de paratge que residien a la vila.

${ }^{39} \mathrm{~A}$ títol comparatiu, a Cervera, per la mateixa època, els preveres estaven obligats a contribuir a raó de $4 \mathrm{~s}$. per mil $(0,4 \%)$ pels seus béns patrimonials com també pels seus beneficis; cf. M. TURULL, El impuesto directo cit., p. 122, n. 161.
} 
beneficis, aniversaris, béns mobles i semovents, considerant que n'estaven exempts per dret especial ${ }^{40}$.

Els preveres maldaren a posteriori per aconseguir l'exempció d'alguns béns. Ja el 1342 s'esmentaven alguns béns que quedaven eximits de contribució, tals com els llibres, vestits i draps de llit, així com també els fruits dels beneficis que els preveres rebien. En les al-legacions fetes el 1394, consideraven que no havien de contribuir pels llibres de les capelles, ni pels calzes ni vestits dels beneficis, ni tampoc pels llibres propis. Tal exempció es feia correspondre a les exempcions consentides als laics sobre les seves armes i sobre les joies de les seves dones. A la sentència del 1395, la seva al-legació fou acceptada justificant-ho en base a una curiosa equiparació ("quamvis arma clericorum sint lacrime et orationes").

Pel que fa als censals, les qüestions exposades eren si fa no fa les mateixes que s'havien plantejat uns anys abans entre la universitat $i$ alguns prohoms, començant per si calia fer contribuir pel cabal o per la renda, o si també havien de contribuir pels censals que percebien fora vila ${ }^{41}$. A nivell més concret, el problema se situava en l'àmbit dels benifets, és a dir, dels censals que eren percebuts a compte de beneficis instituits de cara a la celebració de misses d'aniversari. Els preveres plantejaren el dubte de si calia contribuir pel cabal dels censals dels benifets, dels quals - segons argumentaven en el punt primer de la declaració del 1394- només en tenien l'usdefruït; és a dir, en tant que no eren béns propis, i en tant que amb aquestes rendes no podien fer el que volguessin: ni vendre-les, ni empenyorar-les ni deixar-les en testament. En aquest punt, el jutge d'apel-lacions fou taxatiu: calia que contribuïssin segons l'establert a la sentència del 1392. Davant el dubte que presentaven més endavant respecte també dels cabals dels benifets (punt 13è), el jutge dictaminà que havien de contribuir, atès que treien profit dels fruits dels dits cabals, d'acord amb el principi "qui sentit comodum, sentire debet <etiam > onus". Tocant als censals que rebien fora vila, així de capelles com també a títol propi, els preveres manifestaven altres dubtes (punt $3 \mathrm{r}$ : "con sia cosa clara con si no acguessen res dins lo

\footnotetext{
${ }^{40}$ "quoniam predicta bona iure speciali et favore ecclesie a predictis oneribus (...) penitus de iure sunt exempta". També es diu que, pel que fa als béns immobles $\mathrm{i}$ rèdits patrimonials, havien de contribuir abans que tals béns haguessin passat a les seves mans, probablement en relació als deutes fiscals que devien tenir pendents de temps passat.

"És en aquest punt on es fá al-lusió a la sentència ja promulgada sobre aquestes qüestions amb els censalistes de la vila. en virtut de la qual aquests, pels censals que rebien fora vila, contribuïen per la meitat: sobre això vegeu J. Morelló, Fiscalitat i finances cit. p. p. 335-37.
} 
terme no.ls agueren res demanat"), que igualment foren rebutjats pel jutge d'apel-lacions, que disposà que havien de contribuir de la mateixa forma que la resta de vilatans. És clar que, per aquests benifets, només podien ser gravats de cara a les talles destinades a les obres d'esglésies, segons el que ja hem dit abans.

Les al·legacions dels preveres no s'acaben aquí, ja que encara plantejaven altres dubtes respecte dels béns immobles pertanyents als benifets que eren retornats ("retuts") als preveres: aquests sostenien que no havien de contribuir pels trossos de terra que estaven erms ni tampoc pels albergs, en tant que es tractava de béns improductius o dels quals no n'obtenien cap guany. Tractant-se de béns de capella, la contribució per aquests béns havia de limitar-se a les talles destinades a sufragar obres d'esglésies. D'altra banda, també era important dilucidar si els esplets obtinguts d'aquestes terres (en el cas de què el beneficiat hi cultivés alguna cosa) havien de contribuir com a béns mobles o com a immobles, atesa la desigual contribució basada en aquesta distinció. Davant aquestes al·legacions, el jutge declarà el següent: tocant als erms, calia contribuir en funció del seu valor; i, pel que fa als esplets, aquests havien de ser considerats béns immobles i contribuir com a tals.

Altres dubtes presentats pels preveres portaven la discussió al terreny del propi municipi, en declarar, per exemple, si la universitat havia de contribuir per les pensions que satisfeia a títol de benifets (en aquest punt, hom fa referència a la pràctica, que ja devia ser habitual aleshores, d'enfranquir els censals de qüèsties i altres talles). També l'administració del bací dels pobres vergonyants estava en el punt de mira dels retrets dels preveres, que postulaven si les rendes d'aquest o d'altres bacins havien de pagar en la talla de l'obra de l'església tal com ho feien els benifets. La qüestió era que, si tals rendes no contribuïen pel fet de ser considerades almoines, tampoc haurien de contribuir els benifets, els béns dels quals, en el parer dels preveres, també tenien caràcter d'almoina ${ }^{42}$. A la primera qüestió, respongué el jutge d'apel·lacions que s'havia d'actuar d'acord amb l'estipulat en els corresponents contractes de venda; en el fet dels bacins, es continuaria actuant tal com s'havia fet fins aleshores. De fet, ja en l'arbitrat-

\footnotetext{
${ }^{42}$ Fem avinent que el 1342 s'eximí expressament de contribució municipal ("ab omnibus questiis, servitiis et exactionibus") les capellanies pertanyents o instituïdes per varis prohoms de la vila (cap d'ells clergue) de manera perpetual. Per tant, podem dir que l'enfranquiment d'aquest tipus de rendes s'havia ja iniciat en aquesta època.
} 
ge del 1392 s'havia donat una diposició relativa a aquest tipus d'administració para-municipal: es declarà aleshores que l'administració del bací dels pobres vergonyants estava separada de l'administració principal, de manera que, qualsevol reclamació que es volgués fer havia d'anar adreçada als administradors d'aquells bacins i no a la universitat ${ }^{43}$.

\section{c) Qüestions de procediment}

Finalment, en el procés judicial que ens ocupa hi ha una sèrie de qüestions de procediment derivades de les disposicions fins ara exposades. Igualment, es tracta de qüestions que van ser objecte de successiva regulació en les diferents sentències de les que ens ocupem.

Naturalment, els béns que estiguessin sotmesos a contribució també s'havien de declarar per tal de poder ser taxats d'acord amb el seu valor. El 1342 , a propòsit d'això, es deia que no se'ls podia demanar el jurament habitual en aquest tipus d'operacions. La declaració dels béns immobles (i censals) seria feta pels veïns que coneguessin aquests béns, mentre que la del moble es deixava la decisió als mateixos preveres. Una vegada més, aquestes disposicions estan en consonància amb la voluntat de preservar el diferent estatus jurisdiccional dels clergues. Aquell mateix any, també s'establí que dos dels preveres, que serien escollits anualment pels jurats, havien de ser cridats als consells de la vila (els seus noms serien inscrits a les llistes de concorrents igual com els llecs) per tal d'aconsellar els jurats i per tal d'intervenir en les taxacions de les talles $i$ en les subsegüents rendicions de comptes $^{4}$.

El 1392 s'insistia de nou en la qüestió de la representació, establint que un o dos preveres - escollits, aquest cop, per la mateixa Comunitathaurien d'intervenir en totes les estimacions dels seus béns que calgués fer d'ençà aleshores, així com en les taxacions i col-lectes en les quals haguessin de contribuir ${ }^{45}$; així mateix, també podien intervenir, si volien, en les

\footnotetext{
${ }^{43}$ Des d'aquest punt de vista. la universitat no estava obligada per cap de les deixes de censals que certs particulars de la vila (se n'esmenten cinc) havien fet a favor dels preveres.

${ }^{+4}$ De fet, la designació de dos preveres per avaluar béns i fixar la contribució sembla que. pel que explica Piñas, ja estava contemplat a la sentència del 1319; cf. J. PIÑAS, ob. cir.. p. 128.

${ }^{45}$ Tal és el procediment que veiem practicar en posteriors ocasions i que els propis preveres tenien cura de recordar-ho als jurats. Per exemple, el setembre de 1402 els preveres assignats a fer lestima advertien a un dels jurats $\mathrm{i}$ als estimadors elegits per la vila que la dita estima
} 
corresponents rendicions de comptes. Posteriorment, l'única cosa que s'afegí a la sentència del 1395 (en resposta al dubte formulat pels preveres respecte de si els preveres elegits com a estimadors havien de ser retribuits a mitges entre la universitat i la Comunitat) era que es mantingués la pràctica observada fins al moment; en cas, però, de què tal pràctica fos inexistent, seria la Comunitat la qui hauria de retribuir els comissionats encarregats de fer les estimes dels seus béns; finalment, si tals estimacions eren fetes conjuntament amb les estimes dels vilatans, aleshores llur retribució havia de repartir-se a mitges entre la universitat i la Comunitat, tal com aquells havien reclamat.

Tocant al procés d'estimació, un altre dubte formulat es referia a l'actualització de les declaracions patrimonials, és a dir, si els béns venuts havien de ser anul-lats de l'estima tan bon punt es notifiqués o es tingués notícia del traspàs. En aquest punt, segons la sentència del 1395, calia actuar utilitzant els mateixos procediments que amb els llecs. Els preveres també reclamaren beneficiar-se de les mateixes desgravacions que els llecs, en tot el referent als deutes que tinguessin contrets. També en aquest punt, el jutge d'apel-lacions considerà que els preveres havien de rebre el mateix tracte $(0$, com es diu al document, a fi de servar la igualtat entre uns i altres), beneficiant-se de desgravacions en el cas de què els llecs també fossin desgravats. Una altra qüestió feia referència a les obligacions fiscals que afectaven els seus benifets, així pel que fa a les dècimes com a d'altres subsidis eclesiàstics. En aquest punt, els preveres al-legaven que no podien ser tributaris per les dues parts. El dictamen de micer Andreu Terre s'expressà en el mateix sentit d'abans, o sigui, a favor d'atorgar als preveres el mateix tracte que els llecs.

Això últim planteja la qüestió de fins a quin punt la contribució dels preveres en aquesta fiscalitat justificaria un règim fiscal més suau en relació amb la resta de la població, puix que, després del que hem vist aquí, del que no hi ha dubte és del tracte favorable que rebia aquest col-lectiu en comparació amb la fiscalitat que havia de soportar la població de la vila. El seu règim fiscal era avantatjós gràcies a determinades exempcions (tant d'imposicions com de determinats tipus de talles) i pel grau tan limitat de participació en els impostos municipals, pel fet de contribuir en determinats

s'havia de fer segons l'establert a la sentència i no pas d’altra manera; AHCV, Pergamins, núm. 244. 
tipus de talles i només per determinats tipus de béns. Vist així, no era lògic que, almenys pel que fa a alguns béns com eren els benifets, fossin gravats més que no pas els vilatans, tal com fou estipulat el 1342? Això no obstant, sembla que la participació fiscal dels preveres quedava finalment homologada a la de qualsevol vilatà que percebia censals.

D'acord, però, amb l'estipulat a la darrera sentència, fou necessari conèixer la base imposable de cada prevere (ja hem dit que cap d'ells apareixia registrat a les estimes de 1378). El fet donà lloc a una mena de registre assimilat amb unes estimes (tal és el nom que hom li donà), on s'aplegà informació referida a diferents anys per tenir constància de tots els béns que havien pervingut a les mans dels preveres i de tots els títols de possessió que havien adquirit. Així, el 28-VIII-1399 fou convingut entre els jurats i la Comunitat de Preveres d'examinar els llibres de les clavaries, les juradies $\mathrm{i}$ el manifest per tal de saber a quant pujaven les vàlues de la vila; es prohibia que la taxa de les qüèsties es modifiqués, ni a l'alça ni a la baixa, si no era per via d'estima, o sia, mentre no es fes un nou registre, moment en què es veuria si tals béns havien crescut o minvat de valor ${ }^{46}$.

Altres qüestions de procediment es derivarien de l'incompliment de l'acordat a les sentències, és a dir, pel que fa a la imposició de penes i penyores: el 1342 s'establia que l'acte de compulsió anés a càrrec d'un eclesiàstic escollit pels mateixos preveres per tal de forçar aquells dels seus correligionaris que refusessin o retardessin la seva contribució. Les penyores serien fetes per aquesta persona - a instància, però, del collidor de la qüèstia- donant tres dies de termini per satisfer el deute. Si passat aquest termini no es podia cobrar el deute, llavors la penyora seria traspassada al dit collidor i es procediria a la venda dels béns penyorats fins a cobrir la quantitat deguda. Els preveres quedaven igualment obligats a satisfer les despeses que es poguessin derivar de la seva negativa a contribuir.

Tanmateix, les mesures de caràcter coercitiu no podien ser aplicades sense el vist-i-plau de l'autoritat pertinent. Aquest era un aspecte fonamental,

\footnotetext{
${ }^{46} \mathrm{AHCV}$, Estima dels preveres, fol. $1 \mathrm{r}$. Per exemple. el prevere Guillem Alamany mostrà l’inventari fet el 1379 del testament del seu pare, i es trobà que, segons les anotacions que havia fet el clavari Antoni Cellers el 1380, els béns del pare eren tinguts a $6 \mathrm{~d}$. per lliura $(2.5 \%)$ compresos $25 \mathrm{~s}$. de censal "sogit" i 31 s. "ab lou", per la qual cosa li tocava pagar $33 \mathrm{~s}$. $5 \mathrm{~d}$. pel que fa a béns pervinguts del seu oncle, es va comprovar per un inventari realitzat el 1385 que eren taxats a $7 \mathrm{~d}$. per II. $(2,916 \%)$ i que li tocava pagar per això $55 \mathrm{~s}$. 5 d. malla: ibídem, fol. $2 \mathrm{r}$. Informacions tan detallades com aquestes continuen omplint el registre pel que fa a la resta de preveres.
} 
ja que, altrament, els preveres podien sentir-se desobligats i actuar sense temor a ser mai castigats. Consideraven, com declaraven el 1394, que no estaven obligats a acatar les ordinacions dels llecs ni "en lo fet de les stimes" ni "en altres qualssevol coses". La qüestió fou solventada a la darrera sentència. Segons la declaració feta pública pel jutge, els preveres tenien raó quan deien que les ordinacions dels llecs no afectaven els clergues per disposició de dret (tant pel canònic com pel civil), fins i tot quan tals ordinacions podien tenir alguna utilitat per a ells mateixos; tanmateix, estaven obligats a acatar-les quan es feien amb el decret de l'autoritat, en aquest cas de l'arquebisbe o dels seus oficials. Aquesta puntualització era molt important, ja que d'aquesta manera s'apuntalaven totes les altres disposicions que, altrament, quedarien anul-lades i sense cap efecte.

\section{CLOENDA}

Com hem vist al llarg d'aquest estudi de cas, l'obligació dels preveres de Valls a participar a les contribucions municipals generà una àgria polèmica al llarg del segle XIV que s'anà definint progressivament $i$ a través de diferents pactes (ja des de la dècada de 1340) que consagrà a favor dels preveres un règim fiscal especial. Hem vist que l'època de major conflictivitat es situa a finals del s.XIV, quan s'hagué de recórrer a la via judicial per definir una sèrie de qüestions fins al més mínim detall. El règim fiscal que en resultà, referit sobretot a impostos directes, regulà la forma com els preveres havien de contribuir en determinades talles segons el destí de les mateixes (així mateix, en el cas dels onzens), els tipus de béns pels quals podien ser gravats i la forma de taxar-los, a més de qüestions relatives als procediments que calia seguir en funció de l'acordat en els anteriors punts, és a dir, pel que fa a l'estimació dels seus béns, la seva intervenció en les rendicions de comptes, les mesures per constrènyer els incomplidors, etc.

Els temes al voltant dels quals giren aquests conflictes estan en perfecta consonància amb l'evolució del mateix sistema fiscal del municipi . Ara bé, la pressió exercida sobre el col·lectiu de preveres (en el marc de les múltiples accions promogudes des de l'àmbit municipal per tal d'aconseguir augmentar els ingressos estenent els tentacles de la fiscalitat a un major nombre de persones) podia ser de poc ajut a l'hora d'aconseguir un increment del volum d'ingressos, atès el reduit nombre de contribuents que comptabilitzava aquell col-lectiu. Tanmateix, llur contribució no era gens 
menyspreable quan es tractava de coadjuvar al sosteniment d'algunes despeses, sobretot d'algunes de caràcter comunitari, com les concernents a les obres públiques; amb major motiu, si també s'aconseguia involucrar-los en el pagament del deute municipal. En certa manera, la participació, ni que quedés restringida a unes poques contribucions municipals, d'un col-lectiu que no formava part de la jurisdicció municipal, era un èxit en si mateix. Això sí, el règim fiscal finalment acordat amb els preveres suposava una menor sostracció a nivell global (ja que no es pot dir el mateix en alguns aspectes més concrets) en relació amb el que soportaven els altres contribuents de la vila. Des d'aquest punt de vista, els clergues podien gaudir d'un estatus semi-privilegiat, a mig pas entre l'exempció total i la contribució stàndard.

Amb posterioritat a la sentència del 1395 , els preveres continuaren posant traves al compliment d'aquelles disposicions, arribant a afirmar, per exemple, que cap dels dubtes per ells formulats no havien estat encara resolts $^{47}$ i que la universitat no respectava els termes de la sentència, 0 queixant-se també del fet que eren taxats més del compte ${ }^{48}$. En això últim semblaven tenir raó, ja que, en el cas concret de la talla que aleshores era objecte de la seva reclamació, foren taxats a raó de $7 \mathrm{~d}$. òbol per lliura $(3,125 \%)$, mentre que els laics contribuïen a raó de $6 \mathrm{~d}$. per lliura $(2,5 \%)$. Que els preveres paguessin més que els laics no era veritat - replicaren els jurats-, ja que, "si recte computaretur, ipsi laici plus de XII d. solvunt pro libra, facta computatione impositionum in quibus ipsi presbiteri non

\footnotetext{
${ }^{47}$ Segons les queixes formulades pel procurador de la Comunitat de Preveres el febrer del 1399 a propòsit d'una talla que la universitat estava recaptant. Els preveres avaluaren llurs béns, excloent-hi, però, aquells pels quals havien formulat dubtes, tot esperant que es fes pública la declaració que reclamaven. La universitat respongué que la taxació dels seus béns s'havia fet d'acord amb la sentència, respecte a la qual no hi havia ja cap dubte: "com la dita sentència sie ja prou clara e en res no dubtable". A part, recordaven que l'Oficial i el jutge d'apel-lacions de Tarragona s'havien pronunciat a favor de la universitat en tots els dubtes presentats pels preveres; i com, a pesar de tot, aquests s'obstinaven a interposar més raons, simplement "par què ajen desig e plaer d'aver qüestions e contrasts ab la universitat"; AHCV, Pergamins, núm. 229 (el mateix es recull al perg. núm. 230).

48 "e vosaltres, dits honrats jurats, ab repetida honor no servets ni ajats servada la manera dessús dita, ans ajats avaliats alguns béns dels dits preveres a inmoderada tatxació, e axí matex que alguna partida dels dits preveres encara no sien estats a la dita tatxació, perquè per les rahons dessús dites la dita tatxació fer no podets ne devets"; AHCV, Pergamins, núms. 233 i 234 (ambdós amb el mateix contingut $i$ amb dates límit del 10 al 21 de juny de 1399). Arran d'aquestes queixes, s'inicià el llibre d'estimes al qual ja hem feet al-lusió més amunt.
} 
solvunt"49. Amb aquesta resposta es posava en evidència, doncs, el diferent grau de punció fiscal que requeia sobre uns i altres.

No cal estendre's més en les qüestions que els preveres continuaren interposant durant tots aquests anys, fins almenys el $1408^{50}$. D'ençà aleshores, i fins a mitjan segle $\mathrm{XV}$, tenim la impressió que en bona part es mantingué l'entesa aconseguida a les sentències passades. Com a exponent de la seva submissió, els preveres apareixen ja integrats a les estimes confeccionades al llarg d'aquest segle, encara que, com a prova també del seu règim fiscal diferenciat, s'anoten separats dels altres contribuents, constituïnt una secció pròpia ${ }^{51}$.

En definitiva, el règim establert a finals del segle XIV seguiria vigent, en els seus punts més bàsics, durant força temps, sense que fos de nou necessari establir pactes o emetre noves sentències. Parlem, en tot cas, d'un règim fiscal únic, en tant que les solucions a les quals s'arribà a Valls serien fins a cert punt diferents dels pactes establerts en altres $1 \operatorname{locs}^{52}$. Per

\footnotetext{
${ }^{49} \mathrm{AHCV}$, Pergamins, núm. 235 (dates límits: del 7 al 21 de juny del 1399).

${ }^{50}$ Aquest cop els preveres es queixaven que la universitat havia taxat algunes talles prescindint d'ells i en contra de l'estipulat a la sentència; AHCV, Pergamins, núm. 255.

${ }^{51}$ Per exemple, en el volum del 1445, apareix al final de tot l'estima "dels senyors de preveres", en el qual figuren onze preveres i deu benifets amb el nom del receptor o beneficiat, $i$ tant dels preveres de la vila com d'alguns foranis. Llur estima global, que munta a més de $30.000 \mathrm{~s}$., representa un $4,5 \%$ del total d'aquestes estimes, segons els nostres càlculs. A les estimes de 1485 , els preveres formen també una secció a part (fols. 83 v. -85 v.). De fet, la inclusió de comunitats de preveres $i$ altres associacions eclesiàstiques sembla ser un tret bastant general de les estimes del segle XV, com ja anotava M. TURULL, El impuesto directo cit., p. 108, basant-se en els manifests cerverins. Evidentment, tals anotacions, quan apareixen, i la forma d'aparèixer anotats, dependran dels pactes establerts a cada localitat.

${ }^{52} \mathrm{Com}$ a Valls, el règim establert a Reus també fou resultat de diferents pactes i sentències promulgades al llarg del s.XIV. Això no obstant, les solucions donades a problemes similars varen ser diferents, tal com ja havíem posat de relleu a la nostra tesi: J. MORELLÓ. Fiscalitat i finances cit., p. 618. De forma sintètica, podem fer la següent comparació: pel que fa a les talles, els preveres de Reus. a l'igual que els de Valls, només contribuïen en determinats supòsits, bàsicament restringits a les obres considerades d'interès públic (dins l'àmbit de les talles veïnals) que, ja a la segona meitat del s.XIV, es concretaven en les obres de fortificació i més tard en les obres d'esglésies, però, tret d'aquestes, ja pràcticament no s'indica cap altre motiu. Pel que fa a l'estimació i taxació de béns, mentre que els de Reus havien de contribuir només per la meitat dels béns immobles, els de Valls, com ja hem vist, eren taxats per tots aquests béns $i$, mentre que a Valls eren especialment gravats pels beneficis eclesiàstics, els de Reus havien de contribuir només per la meitat (o ja en res, com sembla fer-se explícit a finals del s.XIV), la qual cosa constituïa una exempció molt important, si considerem que tals rendes podien arribar a ser el seu principal sosteniment. Pel que fa als onzens, a Reus contribuïen nómés per la meitat, mentre que a Valls és probable que no haguessin de contribuir d'acord amb les objeccions que ja hem exposat. Per últim, pel que fa a les imposicions, els preveres de Valls n'estaven eximits totalment (així es declarava el 1399), mentre que els de Reus havien de contribuir únicament pels béns mercadejats. El cas de Reus té similituds amb el que s'observa
} 
tal d'arribar a copsar totes les similituds i totes les dissemblances, cada cas mereixeria un estudi particular. Sense això, esdevé difícil pronunciar-se des d'una perspectiva més general.

a Balaguer, on els clergues estaven exempts de declarar els béns mobles i gaudien d'una reducció del $50 \%$ en la declaració dels immobles; indicat per M. TURULL, El impuesto directo cit., p. 100, n. 85, a partir d'un treball inèdit de Josep Tugues. Igual reducció es troba a la Selva; cf. J. PIÉ, Annals, cit. p. 211. 


\section{APÈNDIX DOCUMENTAL}

1342, gener, 2. Valls.

Compromis subscrit entre la universitat de Valls i els preveres sobre llur contribució a les talles establertes per aquella.

AHCV, Pergamins, núm. 64

In nomine Domini nostri Ihesu Christi. Sit omnibus manifestum quod, cum inter nos, Poncium Adroverii, Guillelmum Çafortea et Johannem Donadei, iuratos de Vallibus, nomine universitatis eiusdem ville et ipsam universitatem, ex parte una, et Berengarium Brocha, Arnaldum de Fraxino, Martinum Reedor, Eymericum Mascharelli, Petrum Arbucii, Bernardum Jover et Guillelmum Carbonelli, presbiteros beneficiatos in ecclesia Sancti Iohannis de Vallibus, et Arnaldum Cabot, Matheum Veya, Raymundum Rayadelli, Guillelmum de Segarre, Monseratum Vinya, Raymundum Brocha, Petrum Avia et Arnaldum Artús, presbiteros deservientes in ecclesia supradicta et habitatores dicte ville, ex altera, questionum materie verterentur super eo quod nos, dicti iurati, nomine predicte universitatis, dicebamus et asserebamus predictos et ceteros presbiteros, habitatores de Vallibus, teneri contribuere cum universitate de Vallibus et singularibus eiusdem in omnibus taliiis et collectis que pro tempore fuerint in predicta villa de Vallibus, sicut alii incole et habitatores dicte ville, de bonis suis patrimonialibus que ad ipsos, ex successione parentum vel ex sua industria seu adquisitione, quocumque titulo, pervenerunt vel pervenient in futurum, sive mobilia sive inmobilia existerent vel existant, et nichilominus de censualibus anniversariorum que comuniter recipiunt vel deinceps recipient presbiteri memorati, et de fructibus sive redditibus beneficiorum suorum sive capellaniarum suarum; nobis, dictis presbiteris, contrarium asserentibus ac dicentibus, quod nos et nostra bona sumus liberi et immunes a quibuscumque talliis sive collectis que per dictos iuratos et universitatem fiant in dicta villa de Vallibus et potissime redditus beneficiorum nostrorum et censualia predictorum anniversariorum. 
Tandem, intervenientibus aliquibus bonis et notabilibus personis que honorem, pacem et concordiam inter nos, dictos iuratos et universitatem predictam, et presbiteros memoratos, affectabant, et, ad omnem dissensionis materiam inter nos et successores nostros in dicto officio et universitatem de Vallibus et dictos presbiteros et que pro tempore erunt, tam beneficiati quam alii deservientes in ecclesia supradicta, totaliter amputandam, et pacem, amorem et concordiam reformandam, talis, inter nos et ipsos, amicabilis avinentia et compositio interesse sit, quod nos, predicti presbiteri et quilibet nostrorum, teneamur contribuere cum universitate de Vallibus et singularibus eiusdem in omnibus talliis et collectis que fient in villa de Vallibus, exceptis pro causis criminalibus, videlicet, de bonis sedentibus et censualibus patrimonialibus, tam ex successione parentum quam ex propria industria, vel alio quovis titulo adquisitis vel decetero adquirendis, sicut singuli de universitate pro equivalentibus bonis contribuere tenebuntur.

De bonis, vero, mobilibus teneamur contribuere cum dicta universitate et singularibus eius pro quolibet millenario solidorum, exceptis libris, vestibus et pannis lecti, et fructibus beneficiorum nostrorum seu caritatis sive stipendii illius anni in quo dicta collecta levabitur, duos solidos.

De anniversariis, autem, contribuere teneamur pro quolibet millenario solidorum, quinquaginta solidos; et, si quantitas censualium dictorum anniversariorum excessit mille solidos, pro quantitate excedente teneamur contribuere pro rata mille solidos.

Et dictos duos solidos de bonis mobilibus et quinquaginta solidos pro millenario censualium anniversariorum vel ultra pro rata teneamur solvere quando et quotiens questie fient in villa de Vallibus, cuiuscumque quantitatis, magne vel modice, fient; etiam, si dicte questie solverentur per obolos seu me $<\mathrm{d}>$ allas. Pro bonis, vero, patrimonialibus et mobilibus et censualibus, et aliis superius nominatis, modum et formam teneamur sequi aliorum in dicta villa habitantium. Si, vero, dicte questie per impositionibus seu adiutam solverentur, ordinationem impositionis sequamur et nichil onmino solvere teneamur.

$\mathrm{Et}$, si contingerit quandocumque quod bona seu bonorum extimatio habeat fieri per iuramentum singularium universitatis quod a nobis, dictis presbiteris, pro extimandis bonis sedentibus seu censualibus et bonis mobilibus iuramentum nullatenus exigatur, set manifestatis per nos bonis inmobilibus et censualibus eorum extimatio fiat per iuramentum vicinorum que noverint ipsa bona. Extimatio, vero, bonorum mobilium nostrorum presbiterorum consciens relinquatur. Verum, ut omnis scandali materia et occasione auferatur inter nos et dictam universitatem, fuit conventum quod coactio seu compulsio fienda nobis, dictis presbiteris, pro solvendis quantitatibus in quibus pro bonis patrimonialibus fuerimus talliati et aliis quantitatibus bonorum mobilium et anniversariorum predictorum, non fiat per laycum set per personam ecclesiasticam hoc modo quod, si aliquis vel aliqui nostrorum in solvendis quantitatibus, nos vel nostrorum aliquem contingentibus, necligentes fuerimus vel 
rebelles, dicta persona ecclesiastica, quam nos habeamus eligere in villa de Vallibus, incontinenti cum per iuratos de Vallibus collector questie fuerit electus seu etiam assignatus, ad requisitionem collectoris dicte questie, nos, dictos presbiteros seu nostrorum aliquem, faciat pignorari et, si infra tridium nos, seu aliquis nostrorum, a tempore capti pignoris non curaverimus solvere, lapso dicto triduo, dictum pignus tradat dicto collectori seu executori suo, qui dictum pignus distrahat sive vendat, et dicto pignore venundato, dicta persona ecclesiastica de bonis nostrorum, dictorum presbiterorum seu alicuius nostrorum, solvere recusantis seu recusantium, tradat seu tradi faciat dicto collectori seu executori predicto tot et tanta de bonis nostris donec de quantitate in quan fuerimus talliati fuerit satisfactum; et, si forte in contentione seu rebellione nostrorum, dictorum presbiterorum vel alicuius nostrorum, non solventis seu non solventium, missiones fient vel expense nostra culpa seu nostrorum, vel alicuius nostrorum, quod ipsos sumptus sive expensas nos, vel nostrorum aliqui renuentes, solvere teneamur.

Et, predicta omnia et singula promittimus nos, dicti presbiteri et quilibet nostrorum, perpetuo tenere et observare, sub tali tamen pacto et conditione quod duo de nobis, naturales ville de Vallibus vel beneficiati in dicta ecclesia que nunc sunt vel pro tempore fuerint, debeant eligi annuatim per iuratos que pro tempore fuerint, et vocari ad omnia consilia que celebrabuntur seu tenebuntur in villa de Vallibus sicut ceteri consiliarii ipsorum iuratorum et ipsorum duorum presbiteriorum nomina inscribantur inter nomina aliorum consiliariorum, qui etiam dicti presbiteri sic annuatim electi teneantur prestare iuramentum, unus videlicet in posse alterius de fideliter consulendo ipsis iuratis et secreti consilii tenendo et nulli pandendo; et, quod dicti duo presbiteri intersint in taxationibus questiarum, intersint etiam cum iurati de gestis per eos reddiderint rationem cum aliquis que per consilium de Vallibus ad audiendum ipsum compotum fuerint assignati.

Item, quod nos, dicti presbiteri, et alii que pro tempore fuerint, dictam ordinationem observantes, possimus, in villa et termino de Vallibus, libere emere bona et mobilia et censualia sicut ceteri habitatores de Vallibus, et quod pro ipsis teneamur contribuere sicut unus de Vallibus habitator, ut superius est dictum.

Item, quod nos et omnes alii dicte ville predictam, ut premittitur, ordinationem observantes, defendamur et manuteneamur sicut alii incole et habitatores ville de Vallibus. Et consequamur libertates et franquitates quas ceteri vicini de Vallibus consequntur. Et quod decetero qualibet, tam clericus quam laycus, possit inter vivos vel in ultima voluntate anniversaria libere ordinare. Et, si qua ordinatio, verbo vel facto, pubblice vel occulte, facta extitit contra nos, presbiteros supradictos, sit cassa et vana, et nullam obtineat firmitatem.

Item, quod capellanie honorabilis Bernardi de Montepavone, Jacobi Marcialis et capellania den Robi et den Messeguer instituta in ecclesia Sancte Marie Magdalenes, Bernardi Arbucii, Bernardi Eymerici, Bernardi de Segarra, Petri Veya, Petri Mila et Sancti Petri et Sancti Michaelis, et Borracie de Fonoleres, ab omnibus 
questiis, servitiis et exactionibus que decetero fient in villa de Vallibus perpetuo sint libere et immunes.

Ad hec nos, dicti Poncius Adroverii, Guillelmus Çafortea et Johannes Donadei, iurati predicti de Vallibus, cum expresso consilio et assensu consiliariorum nostrorum, videlicet, Bernardi Ripol, Arnaldi Dor, Domenici Rossell, Arnaldi Çafortea, Guillelmum de Monteserrato, Mathei Marcialis et Petri de Podio, Bertrandi Clerici, Guillelmi Tarragó, Bernardi Çafortea, Petri Soler, Bertrandi de Tarragona, Guillelmi Piloter, Berengarii de Sanaugia, Berengarii Palau, Guillelmi Palau, Guillelmi de Senaugia, Guillelmi de Ulugia, Arnaldi de Casteló, Jacobi Casseyach, Ferrarii Maschó, Stephani Alamany, Petri Guarch, Petri Cifré, Petri Romei, Berengarii Albanelli, Guillelmi Gavaldà, Petri Cabot, Guillelmi Dorcha, Periconi de Ulugia, Petri de Casteló, Petri Palau, Johannis Martí, Petri de Mandrens, Petri de Corbera, Guillelmi Carbonelli, Guillelmi Manresana, Jacobi Salzes, Berengarii Valès, Johannis Bonshom, Petri Rovira, Berengarii Bernardi, Berengarii Ferrarii, Arnaldi Muntagut, Petri de Valdeperes, Berengarii Granelli, Jacobi Romei, Guillelmi Ferrarii, Bernardi et Petri den Nin, Bernardi Ermengol et Romei Domènech, expresse consentientes et liberaliter nomine nostro et totius universitatis de Vallibus, sub pactis, formia et conditionibus supradictis acceptantes, promittimus vobis, dictis presbiteris et omnibus aliis habitantibus in loco de Vallibus, predictam ordinationem observantibus et nomine infrascripto a nobis nomine vestro et omnium illorum quorum interest vel interesse poterit in futurum quod predicta omnia et singula vobis dictam ordinationem, avinentiam et compositionem, observantibus et tenentibus, observabimus et tenebimus, et in nullo contraveniemus.

Actum est hoc quarto nonas ianuarii anno Domini $\mathrm{M}^{\circ} \mathrm{CCC}^{\circ} \mathrm{XL}^{\circ}$ primo.

$\mathrm{Sig}+$ na nostrorum Poncii Adroverii, Guillemi Çafortea et Johannis Donadei, iuratorum predictorum, que predicta nominibus quibus supra laudamus, concedimus et firmamus.

$\mathrm{Sig}+$ na nostrorum Berengarii Brocha, Arnaldi de Fraxino, Martini Reedor, Eymerici Mascharelli, Petri Arbucii, Bernardi Jover, Guillelmi Carbonelli, Arnaldi Cabot, Mathei Veya, Raimundi Rayadelli, Guillelmi de Segarre, Monteserrati Vinya, Raimundi Brocha, Petri Avia et Arnaldi Artús, presbiterorum predictorum, que predicta laudamus, concedimus et firmamus.

Sig + na Bernardi Ripol, Arnaldi Dor, Dominici Rossell, Arnaldi Çafortea, Guillelmi de Monteserrato, Mathei Marcialis, Petri de Podio, Bertrandi Clerici, Guillelmi Tarragó et Bernardi Çafortea. Sig + na Petri Soler, Bertrandi de Tarragona, Guillelmi Piloter, Berengarii de Sanaugia, Berengarii Palau, Guillelmi Palau, Guillelmi de Sanaugia, Guillelmi de Ulugia, Arnaldi de Castelló, Jacobi Casseyach. Sig + na Ferrarii Maschó, Stephani Alamany, Petri Guarch, Petri Cifré, Petri Romei, Berengarii Albanelli, Guillelmi Gavaldà, Petri Cabot, Guillelmi Dorcha, Periconi de Ulugia. Sig + na Petri de Casteló, Petri Palau, Johannis Martí, Petri de Mandrens, Petri de Corbera, Guillelmi Carbonelli, Guillelmi Manresana, 
Jacobi Salzes, Berengarii Valès et Johannis Bonshom. Sig + na Petri Rovira, Berengarii Bernardi, Berengarii Ferrariri, Arnaldi Muntagut, Petri de Valdeperes, Berengarii Granelli, Jacobi Romei, Guillelmi Ferrarii, Bernardi et Petri den Nin, Bernardi Ermengol et Romei Domènech, consiliariorum predictorum, que predicta laudamus, concedimus et firmamus.

Testes huius rei sunt Guillelmus Cerveró, Jacobus Argilaga, presbiteri, et Petrus Simó.

Sig + num mei Guillelmi Donadei, notarii publici de Vallibus pro venerabili domino Rogerio de Mirapisce, rectore eiusdem, qui hoc instrumentum iam in nudum redactum cum eiusdem notula pro Arnaldum Artusii, condam, notarium dicte ville, recepta fideliter comprobavi, die martis intitulata VIII' ${ }^{\circ}$ idus septembris anno Domini millesimo $\mathrm{CCC}^{\circ}$ quinquagesimo primo et clausi.

1392, abril, 1. Valls.

Sentència donada pels tres àrbitres escollits entre la universitat de Valls $i$ la Comunitat de Preveres (Bernat Ferrer, prevere, Andreu Serra, jurisperit $i$ Pere Çafortea) sobre les contribucions fiscals i altres qüestions mútuament reclamades.

AHCV, Fons Judicial, Sèrie Cort del batlle (sig. top. 1.1.51), fols. 1 r.-16 r.; també a ídem (sig. top. 1.2.48), fols. 187 r.-199 v.

In Christi nomine et eius gloriose virginis Marie. Amen.

Unde nos Bernardus Ferrarii, presbiter, Andreas Serra, iureperitus, Petrus ça-Fortea, ville de Vallibus habitatores, arbitri, arbitratores laudatores et amicabiles compositores comuniter electi et assignati per venerabiles Anthonium Voltor, antiquiorem, Guillelmum de Bas, Petrum Bellot, dicte ville, procuratores et actores ad hoc legittime constituti per venerabiles Anthonium Cellers, Raymundum Certer, Matheum Veyani, iuniorem, iuratos et sindicos universitatis dicte ville, de expresso consilio et assensu ac voluntate ${ }^{1}$ totius universitatis eiusdem, ex una parte, agentes et deffendentes, et per venerabiles Bernardum Ferrarii, Petrum Guarch, Petrum Rebusterii, presbiteros et benefficiatos dicte ville, procuratores, actores et yconomi legittime constituti a tota comunitate presbiterorum et clericorum dicte ville et

\footnotetext{
'A la còpia (1.2.48) apareix interliniat "totius consilii generalis dicte ville nomine et vice" abans de "totius universitatis eiusdem".
} 
singularium eiusdem, ex altera, agentes et deffendentes ratione contributionis et aliarum actionum per utramque partium factarum ut in compromisso inter et per dictas partes facto et firmato in posse discreti Bernardi Morató, notarii publici dicte ville, $\mathrm{XXX}$ die mensis septembris anno a Nativitate Domini $\mathrm{M}^{\circ} \mathrm{CCC}^{\circ}$ nonagesimo primo, et in processu inde facto latius dignoscitur contineri.

Viso primitus dicto compromisso et potestate per eundem nobis atributa; viso etiam et bene ruminato toto processu rationibus predictis in posse nostrum et dicti notarii inter dictas partes facto et (attitato); visis etiam omnibus probationibus, tam iuris quam facti per dictas partes productis et oblatis, habito super hiis sano et maturo consilio cum pluribus eximis doctoribus et aliis iurisperitis, et specialiter et signanter cum honorabilibus et providis viris domino Petro Pascasii, in utroque iure doctori, domino Michaele de Sancto Johanne, in utroque iure licenciato, domino Bernardo Lunes, antiqui et valde famosi in utroque iureperiti, omnibus habitatoribus civitatis Barchinone, sacrosanctis evangelis coram nobis prepositis et reverenter inspectis ut de vultu Dei nostrum prodeat iuditium et occuli nostre mentis videant equitatem, sedente pro tribunali more maiorum recte iudicantium, diem presentem dictis partibus ad audiendam sententiam seu declarationem assignatam; eligentes viam amicabilis compositionis non tamen a tramite iure deniantes. Immo, in quantum nostrum et dictorum dominorum iurisperitorum supra nominatorum posibile fuit veras et determinatas iure decisiones et determinationes super hiis sequentes, partibus predictis presentibus, et sententiam seu declarationem fieri postulantibus, pronuntiamus, sententiamus et declaramus in et super predictis et infrascriptis per modum qui sequitur:

Primo, venientes ad petitionem seu demandam factam per dictos procuratores dicte universitatis contra procuratores clericorum et ipsos clericos, declaramus et pronuntiamus quod dicti presbiteri et clerici et quicunque alii benefficiati in dicta villa de Vallibus habeant et teneantur solvere et contribuere in futurum in operibus ecclesiarum, cimbalorum, squillarum et aliorum operum piorum fabricarum ecclesie vel similia concernentium, in quibus omnibus et singulis contribuere habeant per quibuscumque eorum bonis et ecclesie, tam propriis quam benefficiorum quam anniversariorum et aliorum quorumcunque quemadmodum, et prout laici dicte ville de Vallibus in dictis operibus pro eorum bonis contribuent in futurum.

Pari modo, pronuntiamus et declaramus quod dicti presbiteri et clerici habeant et teneantur solvere et contribuere in futurum in operibus pontium, viarum, itinerum pubblicorum, salariorum de viyògolls, medicorum et aliorum honerum similium utilitatem comunem dictorum clericorum et laycorum concernentium, pro eorum tantum bonis propriis patrimonialibus seu aliunde que sitis, inmobilibus tantum et redditibus prout layci dicte ville in eisdem operibus et pro eorum bonis contribuent in futurum. Intelligimus, tamen, quod dicti presbiteri et clerici non teneantur contribuere in predictis pro bonis ecclesie benefficiorum nec anniversario- 
rum nec pro bonis eorum propriis patrimonialibus seu aliunde que sitis, mobilibus seu se moventibus.

Simili modo, pronuntiamus et declaramus quod dicti presbiteri et clerici habeant et teneantur solvere et contribuere in futurum in operibus murorum vallium in dicta villa de novo fiendorum seu reficiendorum pro custodia dicte ville, et hoc pro eorum tantum bonis inmobilibus et redditibus patrimonialibus seu aliunde que sitis, prout ipsi laici dicte ville in eisdem operibus pro eorum bonis contribuent in futurum, non tamen pro bonis ecclesie benefficiorum nec anniversariorum nec pro bonis propriis dictorum clericorum mobilibus seu se moventibus aliquomodo contribuere teneantur, nec etiam ullomodo teneantur contribuere in muro nec vallo faciendo in dicta villa pro murando seu intus murum ponendo monasterium fratrum del Carme ibi constructum seu edifficandum, in quibus muro et vallo del Carme declaramus dictos presbiteros et clericos in aliquo non teneri.

Eodem modo, pronuntiamus et declaramus quod dicti presbiteri et clerici habeant et teneantur solvere et contribuere in oneribus dicte universitatis tempore preterito factis pro eorum tantum bonis inmobilibus et redditibus patrimonialibus seu aliunde que sitis, in illis tamen honeribus per dictam universitatem factis antequam ipsa bona ad manus et posse dictorum presbiterorum et clericorum pervenissent, quoniam in aliis oneribus factis post quam dicta bona in manibus et posse dictorum clericorum pervenerunt, declaramus dictos presbiteros et clericos in aliquo pro predictis non teneri. Et eadem forma servetur in dictis bonis inmobilibus seu redditibus que in futurum pervenient in manibus presbiterorum seu clericorum, videlicet, quod solvant pro oneribus factis et fiendis per ipsam universitatem donec ipsa bona ad manus et posse dictorum clericorum pervenient.

Declaramus etiam bona propria ecclesie benefficiorum et anniversariorum et bona mobilia seu se moventia dictorum clericorum ad predicta ullo modo teneri, quoniam predicta bona iure speciali et favore ecclesie a predictis oneribus, etiam contractis antequam ad ecclesiam pervenissent seu pervenient penitus de iure sunt exempta.

Super aliis petitis per dictam universitatem seu eius procuratores, videlicet, super expensis usque nunc factis per dictam universitatem in operibus murorum, vallium, ecclesiarum, itinerum, pontium et omnium aliorum operum et expensarum que inter omnia summa capiunt ut ex petitione ipsorum apparet ad viginti mille florenos et in quibuscunque aliis per dictam universitatem petitis eidem universitati cum presenti et ex causa scilentium inponimus sempiternum.

Venientes ad petitionem per dictos presbiteros factam contra dictam universitatem, declaramus:

Primo, dictos procuratores seu ipsam universitatem in aliquo non teneri in illis LX mille sol. per ipsos presbiteros petitis pro inpositionibus per ipsos clericos seu presbiteros, ut asserunt, tempore preterito solutis in pane, vino et aliis eorum 
vite necessariis per ipsos emptis; immo in eisdem ipsis presbiteris et clericis cum presenti scilentium inponimus sempiternum.

Simili modo, pronuntiamus et declaramus dictos procuratores dicte universitatis seu ipsam universitatem aliquomodo non teneri dictis presbiteris et clericis in illis LXVI mille CCC solidis per dictos presbiteros seu eorum procuratores petitis illa ratione ut asserunt, quia non promiserunt eis vendere vinum sine inpositionem; immo, de illo vino quo ipsi clerici vendebant, habeant solvere inpositionem, videlicet, $\mathrm{V}$ sol. pro saumata; et, quia illos quinque sol. solvunt ementes et non vendentes. Ideo, declaramus dictam universitatem dictis presbiteris in dictis LXVI mille CCC sol. per ipsos presbiteros petitis ratione predicta aliquomodo non teneri ipsis presbiteris, super eisdem scilentium cum presenti inponendo.

Declarantes quod ex quo illa inpositio dictorum quinque solidorum pro salmata inponitur in illa mensura vini vel ab ipsa mensura deducitur et ideo ipsos quinque sol. solvent layci ementes et non ipsi clerici vendentes, quod decetero ipsi presbiteri et clerici habeant et teneantur vendere vinum laycis cum inpositione ad quod faciendum ipsos presbiteros et clericos cum presenti condempnamus.

Pari forma, pronuntiamus et declaramus dictos procuratores dicte universitatis seu ipsam universitatem in aliquo non teneri eisdem presbiteris et clericis pro hospitiis, ortis et aliis possessionibus dirutis propter muros et valla dicte ville, neque in censualibus seu quibusvis redditibus benefficiorum seu adniversariorum (sic) predictis propter edificationem dictorum murorum et vallium; ymmo, in eisdem omnibus et in quantitate centum mille solidorum per ipsos presbiteros ratione predicta petita eisdem presbiteris et clericis cum presenti et ex causa scilentium inponimus sempiternum.

Declaramus, tamen, quod, si in futurum per dictam universitatem fieret generalis smenda, satisfactio seu restitutio predictorum propter muros et valla destructorum laicis seu aliis habitantibus in dicta villa, quod eodem modo et per eandem formam fiat restitutio et smenda ipsis clericis pro bonis et redditibus benefficiorum et anniversariorum ratione predictorum murorum et valla destructorum, et non pro aliis bonis.

Declaramus etiam et pronuntiamus dictos procuratores dicte universitatis seu ipsam universitatem non teneri ad illa censualia per ipsos presbiteros petita et ipsis presbiteris per Bernardum de Muntornès, Guillelmum de Muncades, Petrum Mascó, Fferrarium Mascó, Petrum de Muntornès dimissa, cum ipsa universitas ad ipsa censualia non sit obligata, cum ipsa administratio bacini pauperum verecumdantium sit separata ab administratione dicte universitatis et nichil habeat comune cum ea. Salvamus, tamen, ius et actionem dictis clericis quamcumque habeant contra dictos administratores dicti bacini pauperum verecundantium, super quibus per presentem nullum intendimus fieri periuditium. Super aliis omnibus per quamlibet partium 
predictarum petitis cuilibet ipsarum, cum presenti scilentium inponimus sempiternum.

Pronuntiamus etiam et declaramus quod unus vel duo presbiteri seu clerici dicte ville, ille vel illi quem vel quos presbiteri dicte ville vel maior pars eorum eligerint, interveniant in stimationibus vel valiationibus bonorum ipsorum clericorum seu presbiterorum tantum et non laicorum in posterum per dictam universitatem fiendis et non ${ }^{2}$ in tatxationibus questiarum seu collectarum per dictam universitatem in posterum fiendarum, tam clericis quam laicis; et hoc, si interesse voluerint; hoc tamen intelligimus quod intersint in illis tallis et collectis in quibus ipsi clerici seu presbiteri fuerint in aliquo tatxandi; in aliis, autem, non debeant interesse; similiter debeant vocari et interesse si voluerint in audiendo compotum de predictis quando reddetur.

Pronuntiamus etiam et expresse retinemus quod, si in presenti sententia seu declaratione forent de presenti seu in posterum apparuerint, emergerint seu inciderint principaliter vel incidenter vel alio modo aliqua dubia seu obscura que indigeant seu requirant aliquam declarationem, decisionem seu interpretationem, quod illa, infra tempus dicti compromisi vel postea, posimus declarare, determinare seu interpretare prout nobis visum fuerit faciendo.

Item, mandamus dictis partibus et cuilibet ipsarum quatenus presentem sententiam seu declarationem ante quam a nostrorum presentia recedant, laudent, approbent et emologent, et omnia et singula in eadem contenta, teneant et observent sub penis et iuramentis in compromisso ratione predicta inter ipsas partes facto apositis, prestitis et contentis. Et, per modum predictum, declaramus nos dictis arbitri, arbitratores et amicabiles compositores inter dictas partes neutram dictarum partium in expensis condempnando.

Lata, lecta et recitata fuit hac sententia arbitralis et declaratio per dictos venerabiles dominos et providos viros Bernardum Fferrarii, presbiterum, Petrum çaFortea et Andream Serra, iureperitum ville de Vallibus, arbitros, arbitratores, laudatores et amicabiles compositores in platea macelli sive de la Carneceria dicte ville, iuxta cohopertam ponderis farine eiusdem ville sedentes et existentes, die lune hora completori qua computabatur prima dies mensis aprilis anno a Nativitate Domini $\mathrm{M}^{\circ} \mathrm{CCC}^{\circ}$ nonagesimo secundo, presentibus venerabilibus Antonio Cellers et Raymundo Certer, iuratis et sindicis hoc anno prefate ville, et Antonio Voltor, Guillelmo de Bas et Petro Bellot, procuratoribus et actoribus universitatis eiusdem ville, ex una parte, et venerabilibus et discretis Petro Guarch, Petro Rebuster et Bernardo Vallès, presbiteriis, procuratoribus et yconomis venerabilis comunitate presbiterorum iam dicte ville, ex parte altera; hanc sententiam arbitralem et declarationem requirentibus et postulantibus et presentibus etiam testibus ad hoc

\footnotetext{
'A la còpia aquest "non" no apareix indicat.
} 
vocatis, sumptibus et rogatis venerabilibus Laurentio Natalis, iureperito, Bernardo de Tamarito et Galcerando de Passanant, domicellis, Guillelmo Ferrarii, de domo domine regine Iherusolemitani et Cipri, Bernardo de Tamarit, paratore, Arnaldo Segura, seniore, Romeo Cabot et discreto Berengario de Mianès, scriba venerabilis curie dicte ville, et Jacobo Tonet, scriptore de Vallibus, et pluribus aliis habitatoribus dicte ville ibidem existentibus; et presente me, Bernardo Morató, notario infrascripto; et omnes dicte partes prolata et dicta et lecta sententia et declaratione eam, et omnia in ea contenta (mor) laudarunt, approbarunt, emologarunt et confirmarunt.

Sig + num mei Bernardi Morató, notarii publici ville de Vallibus pro venerabili Bernardo de Campis, rectore ecclesie eiusdem ville, qui hec scribi feci et clausi cum (supra)posito in XXXVII linea ubi legitur "in eadem".

1394, gener, 1. Valls.

Dubtes presentats pels procuradors de la Comunitat de Preveres als àrbitres del plet $^{3}$.

AHCV, Pergamins, núm. 205: copiat també a Pergamins. núm. 203 (entre altres actes relacionats amb el plet).

Noverint universi quod die sabbati, hora vesperorum, qua computabatur decima dies mensis ianuarii, anno a Nativitate Domini millesimo trecentesimo nonagesimo quarto, in presentia mei, Bernardi Morató, notarii infrascripti, et in presentia etiam venerabilis magistri Petri Rogeri, medici, et Petri de Monteaccuto, ville de Vallibus, testium ad hec specialiter vocatorum et assumptorum, venerabili et discreti Petrus Rocha et Jacobus Natalis ${ }^{4}$, presbiteri et procuratores venerabilis comunitatis presbiterorum dicte ville, prout constat per procurationis instrumentum receptum per me supra et infra scriptum notarium octava die mensis augusti anno a Nativitate Domini millesimo trecentesimo nonagesimo tertio ad hec et plura alia sufficiens et completum, prout in ipso latius continetur, dictis nominibus constituti coram presentia venerabili Petri ça-Fortesa, dicte ville, in domo sua personaliter

${ }^{3}$ Tot el que s'exposa en aquest document és en certa manera ampliació d'una anterior apel-lació que es féu el 18-XII-1392, segons consta a AHCV, Pergamins, núm. 199 (enmig d'altres apel-lacions i respostes donades). Com a complement, escriurem en nota els dubtes exposats el 1392 dels que són correlatius als de 1394.

"A la còpia (mim. 203) apareix escrit "Nicolai" en lloc de "Natalis". 
inventi, obtulerunt et presentarunt, et per me, dictum et infrascriptum notarium, legi et publicari, requisiverunt et fecerunt dicto venerabili Petro ça-Fortea, ut conarbitro cum venerabili Bernardo Ferrarii, presbitero, et Andrea Serra, iureperito, in causa arbitrali que ventilata extitit inter venerabilem universitatem dicte ville, ex una parte, et venerabilem comunitatem presbiterorum predictam, ex altera parte, quoddam folium papiri dubia in se continens tenoris sequentis:

En la presència de vosaltres, honrats àrbitres e arbitradors constituïts procuradors dels preveres de Valls e comunitat d'aquells en Pere Rocha e en Jacme Nadal, preveres, requeren a vosaltres, dits honrats àrbitres e arbitradors que per lo poder que.us avets retengut e aturat de declarar los duptes següents, los quals an mester necessàriament declaració.

Primo, que com en lo primer capítol sien contenguts que los dits preveres e altres beneficiats sien tenguts de paguar e contribuir en l'esdevenidor en les obres de les esgléyes et cetera, e de aquest capítol ischa aquest dupte, ço és, si los preveres qui han tan solament lo ús defruyt en los lurs benifets que no antenen ésser tenguts del cabal dels censalls dels benifets com no sien lurs propris ni no.n pusquen fer a lur voler, ni vendre, ni enpenyorar, ni jaquir a negú en testament ni en altra manera $^{5}$

Secundo, que no entenen ésser tenguts de contribuir per los libres de les capelles, calzes, vestiments ni de libres lurs propriis, joyes són lurs axí com dels lechs són les armes e les joyes de lurs mullers, com no.n contribuexen en res'.

Tertio, que no entenen ésser tenguts de contribuir dels censals que han de fora lo terme, axí de capelles com lurs propris, com sia cosa clara con, si no.n haguessen res dins lo terme no'Is hagueren res demanat ni dit ni feta qüestió deguha, com ells no paguen ni contribuexen dels censals que han fora lo terme sinó per la meytat, e açò és stada avinença que an feta entre ells, en la qual avinença los dits preveres no.y són entesos, com ells no puxen fer avinences ni ordinacions sobre ells.

tai. Quarto, que entenen que los deutes que deuen los deuen ésser relevats de la stima, car la sentència no $1 l$ condampnà sinó en ço que han?.

Quinto, que com alguns troços de terra sien retuts als dits preveres per los censals qui són dels benifets e propris lurs que no $n$ han res, ans si perden los

\footnotetext{
${ }^{5}$ Això mateix, en les apel-lacions del 1392 |punt Ir|, s'expressava de la següent manera: "si clerici tenentur contribuere de proprietate ac capitali censualium benefficiorum et aniversariorum de quibus nil disponere possunt presbiteri nec facere suas voluntates, nisi de annuali. cum sit proprietas benefficiorum que alienari non potest, prout layci possunt de illas proprias voluntates, et ius non permitet quod ad imparia indicentur".

${ }^{6}[1392$, punt $2 n]$ "quod sicut layci arma et iocalia uxoris non ponunt in contributionibus, ita nec clerici libros, calices, vestimenta benefficiorum nec libros proprios, que sunt iocalia ipsorum clericorum in contributionibus ponere debent, quare non ad imparia et cetera".

7 [1392, punt $3 r /$ "quod debita que debentur predictos presbiteros non debent poni in contributionibus cum sic es alienum, non proprium ipsorum presbiterorum".
} 
censals e estan erms e incultivats, ni dels alberchs qui són propris dels benifets, que d'aquests aytals no entenen ésser tenguts de fer estima ni contribució deguna, car res no.n hajen ${ }^{8}$.

Sexto, que com algun troç de terra dels benifets sia retut algun beneficiat, lo qual és erm e incultivat, e lo beneficiat lo conreerà, ço és asaber, que.y sembrarà blat o altres coses, o.y farà vinya, e aquell si és tengut de contribuir sinó en obres de esgléya, con sien béns de capella9.

Septimo, que con en la sentència los condampnà de paguar en una manera en lo moble e en altra manera per lo siti, e com la stima se farà los blats e la venema e altres splets seran en les terres, e en aquell cas los dits splets si seran dits mobles o si no.

Octavo, que com los censals dels dits benifets reben e tots anys n'agen a pagar dècimes, talles, subsidis, visitacions e altres càrrechs, e en aquest cars $\mathrm{si} \cdot \mathrm{ls}$ serà relevats de la stima, car ells no poden ésser contributaris en dues maneres, o an a ésser franchs de la una o de la altra ${ }^{10}$.

Nono, si donen o venen algunes proprietats $\mathrm{si} \cdot \mathrm{ls}$ deuen ésser relevades de la estima tantost, car ells no sien tenguts a ordinacions et cetera ${ }^{\prime \prime}$.

Decimo, e si són tenguts de estar a les ordinacions dels lechs en lo fet de les estimes ni altres quals sevol coses'?.

Undecimo, si la vila és tenguda de pagar per los diners que tenen dels benifets dels quals fan interès als beneficiats e en la venda fan-los franchs de questes e de totes altres coses, en aquest cars entenen los dits preveres que la dita vila o deu pagar, cars que tenguts sien dels cabals o preus contribuir los dits beneficiats.

Duodecimo, com ací haje un bací de pobres vergonyans lo qual ha bé cent llrs. de renda poch més o meyns, e d'altres bacins que han rendes, e aquests si seran tenguts de pagar en la questa de la obra de la esgléya axí com los benifets, car axí són bé almoyna los béns dels dits benifets com dels dits bacins.

\footnotetext{
${ }^{8}$ [1392, punt 4rt] "quod de terris restitutis ipsis beneficiatis pro benefficiis suis incultis remanentibus, ipsi presbiteri non debent contribuere, cum remaneant inculte (iquis?) non debeat gravarii, ex eo quare comodum non habent".

'[1392, punt $5 \grave{e}]$ "si presbiteri, in terris restitutis ipsis de suis benefficiis operantibus, et bladum seu vineam facientibus, tenentur solum contribuere in operibus ecclesiarum et similium, et non in aliis" o bé (punt 6è) "qualiter solvere debent presbiteri in contributionibus uno tenore sunt seminata ipsorum vel in alia sunt fructus et qualiter quorum sunt steriles".

${ }^{10}$ [1392, punt $\left.7 \grave{e}\right]$ "si presbiteri cum de censualibus benefficiorum suorum solvant plura onera, ut decima et subsidia, si de contributione debent relevari dicta onera".

"/1392, punt 8è] "si presbiteri vendant aliquam proprietatem, si illa proprietas debet incontinenti relevarii ab extima".

12/1392, punt 9è "si presbiteri habent servare in presbiteris ordinationes laycorum".
} 
Tertiodecimo, en cars que los preveres fossen tenguts de pagar dels cabals dels benifets que entenen que no sien tenguts de pagar de ço del lur propri, mas que.n pach dels cabals mateixos, car no sia cosa lur pròpia.

Quartodecimo, com la vila hage feta talla per la obra de la esgléya e an ordonat de pagar un diner per lliura e quatre sols. d'altre part de sobre messa, si són tenguts de pagar los dits preveres los dits quatre sol.

Quintodecimo, com los jurats e pròmens hagen ordonat que paguen onzè de pa e de vi e de totes altres coses que hagen ni cullen, e si los dits preveres clergues són tenguts de pagar onzè, la qual cosa no entenen ésser tenguts ni obligats et cetera $^{13}$.

Sextodecimo, si aquells preveres que són stats a altres estimes a fer per part dels dits preveres deuen ésser satisfets per los preveres solament o per los preveres e lechs ensemps.

Perquè los dits procuradors o procurador requeren a vosaltres honrats desús dits arbitradors que tots los desús dits duptes declarets en tal forma e manera que tota qüestió ces e sia tolta entre los dits preveres e clergues, d'una part, et los jurats e prohòmens de la dita vila de Valls, d'altra, en bona concòrdia sia e romanga entre aquells, axí com deu ésser e romandre e de aquells se pertany, protestant que los dits procurador o procuradors no.n entenen en alguna manera ni los dits preveres venir contra la sentència, ans aquella entenen en tot e per tot observar segons que és dada per ells e amologada e servada e loada, e afermant los dits procurador o procuradors en lo nom que desús que ells e los dits preveres són prests e apparellats de observar en tot e per tot les declaracions que per vosaltres, dits honrats àrbitres e arbitradós fetes seran, e, de les coses desús dites, totes e sengles, los dits procurador o procuradors requeren ésser carta o cartes aytantes con necessari los seran.

Quo quidem folio papireo, ut predicitur, presentato et per me, dictum et infrascriptum notarium eidem venerabili Petro ça-Fortea, lecto et publicato, et tradita copia de eodem, incontinenti dicti venerabili procuratores requisiverunt de premissis eisdem fieri et tradi publicum instrumentum.

Post hec eadem die, hora, mense et anno predictis, quasi incontinenti, dicti venerabili procuratores honorabilis comunitatis presbiterorum iam dicte ville, presentibus Bernardo Gavaldà, loci de Milano, et Bartholomeo Mulet, filio Jacobi Mulet, ville de Vallibus, testibus ad hec vocatis et assumptis, obtulerunt et presentarunt, et per me, dictum et infrascriptum notarium, legi et publicari, requisiverunt et fecerunt venerabili Bernardo Ferrarii, presbitero et conarbitro predicto, in ciminterio ecclesie maioris dicte ville personaliter invento, preinsertum

\footnotetext{
${ }^{13}$ En la còpia del pergamí núm. 203 el punt catorzè figura com a quinzè i, a l'inversa, el quinzè figura com a catorzè.
} 
papiri folium, et tradita copia de eodem eidem, incontinenti dicti venerabili procuratores requisiverunt de predictis omnibus et singulis eisdem fieri et tradi pubblicum et pubblica instrumentum tot quod voluerint.

Que fuerunt acta die, hora, mense et anno predictis, presente me, dicto et infrascripto notario, et presentibus testibus antedictis prout superius latius continetur.

Sig + num mei Bernardi Morató, notarii publici, ville de Vallibus, per venerabili Bernardo de Campis, rectore ecclesie eiusdem ville, qui hoc scribi feci et clausi.

1395, abril, 30. Tarragona (castell de l'arquebisbe).

Sentència donada pel jutge d'apel-lacions, micer Andreu Terre, aclarint els dubtes presentats pels preveres després de la sentència arbitral de 1392 i de la declaració feta per l'Oficial de Tarragona.

AHCV, Fons Judicial, Sèrie Cort del batlle (sig. top. 1.2.51), fols. 17 r.-29 r.: copiat també a Pergamins, núm. 203 (enmig d'altres actes judicials relacionats amb el plet)

Ihesu Christi nomine invocato. Ego, Andreas Terreni, inter minimos legum doctor iudex, comissarius in presenti causa appellationis per reverendissimum in Christo patrem et dominum Enecum, divina providentia archiepiscopum Terracone, datus et assignatus, prout de comissione michi constat; visis in primis appellatione facta pro parte comunitatis presbiterorum ville de Vallibus a quadam sententia diffinitiva lata per honorabilem fratrem Petrum de Casis, ut comissarium ab eodem domino archiepiscopo datum in primitiva causa et appellationis inde datis; visis inquam libello appellatorio per partem appellantem oblato et responsione eidem facta, litem legitime contestando de inde attentis et ad plenum rumiatis quibusdam positionibus se articulis gravamina appellationis exprimentibus et responsionibus inde secutis, et nonnullis instrumentis publicis per partem appellantem productis, requisitiones factas venerabilibus arbitris super nonnullis dubiis in se continentes; visa inquam, et cum studio recensita, quadam sententia arbitrali inter universitatem ville de Vallibus agentes et deffendentes, parte ex una, et comunitatem presbiterorum similiter agentes et deffendentes, parte ex alia, per venerabiles arbitros per utramque partium electos lata, ex quaquidem sententia arbitrali et contentis in eadem dubia, de quibus lis inter dictas partes ducitur, ortam fuerunt, et quamquam durum sit lites ex litibus oriri nam sententia, ideo dicitur res iudicata quare finem controversiam pronuntiationem iudicis accepitur bene quare inter dum predicta veniunt culpa 
partium cum connetur res claras in dubium revocare, visis et attentis dubiis inde ortis et omnibus aliis et singulis que dicte partes coram me, iudice comissario, dicere, proponere seu allegare voluerint verbo pariterque scriptis divinisque scripturis coram me positis et eis reverenter inspectis, ut de vultu magestatis divine meum prodeat iuditium et occuli mei videre valeant equitatem et ius suum cuique possit reddi, die per me dictis partibus ad sententiam audiendam perempte assignatam in hiis scriptis, pronuntio in modum qui sequitur:

Cum constet michi, iudici comissario antedicto, honorabilem officialem iudicem, comissarium in prima causa se retulisse ad sententiam arbitrorum inde super contributionibus qui habent fieri in dicta villa de Vallibus latam et ad causas ibidem expressatas non curando de nomine impositionis oneris, sive illud vocetur onzè sive quocumque alio nomine nuncupetur, cum natura rerum plura sint negotia quam vocabula sed solum deffectu ipsius impositionis, cum actio seu res in locum alterius subrogata sapit vim et naturam illius in cuius locum subrogatur, et dubia inde orta non inpediebant sententie probationem; idcirco, pronuntio et declaro bene fore pronuntiatum et male per comunitatem presbiterorum appellatum, et cum regulariter in causa appellationis appellans victus venit in expensis condempnandus, ideo, partem appellantem in expensis presentis cause appellationis condempno tatxatione ipsarum expensarum michi imposterum reservata.

Verum, quia ad officium boni iudicis spectat dubia inde orta declarare, cum omnis sententia debeat esse clara, lucida et certa, et quamvis venerabili arbitri in eorum sententia retineverint quod, si quod esset dubium seu obscurum, illud ipsi possent dilucidare et declarare, et per instrumenta publica per partem appellantem coram me producta et allegata constet quod per ipsos arbitros non fecisse (quando) dubia fuerunt declarata, sed pro parte requirente dubia declarari, quia non sufficit verbo dicere de solvendo sumptus nisi opere adimpleatur, et licet predicta pronuntiatio per me facta sufficeret; verum, quia partes in futurum melius comptentabunt et presens causa remanebit sine litte, cum voluntatis questio inter contraentes in arbitrio sit iudicantis; idcirco, equitatem habens pre occulis mentis mee et ut sententie inde late clarius et melius executioni debite demandentur, cum aliud parum prodesset sententias ferri, nisi executioni debite mandarentur super dubiis inde ortis et motis in et super sententia arbitrali et quolibet eorum, pronuntio et pronuntiando declaro in modum sequentem:

Primo, ad primum dubium dico et dicendo pronuntio et declaro quod, attentis et consideratis verbis apositis in primo capitulo sententie venerabilium arbitrorum et effectum eorumdem, quod dicti presbiteri contribuere teneantur de capitali censualium beneficiorum et hoc propter verbum apositum in sententia ibi cum dicit "pro quibuscumque eorum bonis et ecclesie, tam propriis quam beneficiorum", et sic non obstat aposito neque dubium, nam quamvis capitalia censualium non sint clericorum nisi quo ad usum fructuum sunt tamen ecclesie. 
Ad secundum dubium modo predicto dico quod, si homines ville de Vallibus in perequationibus quas faciunt de bonis eximunt a contributionibus onerum iocalia mulierum et arma, tunc dico eo casu quod presbiteri non teneantur pro iocalibus ecclesie neque suis, sicuti sunt calices, vestimenta, libri et alia iocalia neque pro armis quas habebunt, quamvis arma clericorum sint lacrime et orationes.

Ad tertium dubium, dico simili modo quod pro censualibus que recipiunt dicti presbiteri extra villam et terminos dicte ville contribuant in oneribus in primo capitulo sententie arbitrorum comprehensis et sicuti homines habitantes in dicta villa contribunt de consimilibus censualibus, et non in plus.

Ad quartum dubium, dico quod, quamvis de iure bona non dicantur nisi deducto ere alieno, verum quare in perequationibus fiendis de bonis super materia contributionum equalitas est servanda, idcirco sententio quod, si homines ville de Vallibus in extima quam faciunt de bonis eorum levant debita et credita, quod simili modo fiat in bonis presbiterorum, aliud non.

Ad quintum, dico et in eo pronuntio quod talia bona herema debent estimari in valore in quo nunc sunt, et secundum illorum valorem dicti presbiteri debere contribuere in oneribus antedictis.

Super sexto dubio, duco declarandum quod, si bene arbitralis sententia iuspiciatur clara est super sexto dubio moto, videlicet, quod illa bona de quibus expressa mentio sit in dubio presenti teneantur solum ad honera in primo articulo in sententia expressa, ad alia vero non.

Ad septimum dubium, dico et duco declarandum quod, attento quod iura dicunt et volunt quod fructus pendentes pars domini fore censentur, idcirco pronuntio pro inmobilibus eo casu reputari et loco inmobilium haberi et tanquam pro bonis inmobilibus contribuere debere.

Super octavo, dico quod presens dubium potest recipere declarationem per ea que dixi supra proxime in quarto articulo, videlicet, quod, quamvis de iure omnia talia honera sint deducenda tanquam ordinaria, verumtamen, quia ut dixi equalitas in oneribus sit servanda, duco super hiis declarandum quod, si homines ville de Vallibus ibidem habitantes alia onera ordinaria relevant in eorum extimationibus et perequationibus antequam veniant ad alia onera extra ordinaria, quod eis viis et terminis et similimodo pertineant et perequantur presbiteri et clerici dicte ville de Vallibus.

In et super nono, dico quod fiat in ipsis sicuti in ceteris habitantibus in villa de Vallibus, dum tamen fiat sine fraude clericorum.

Ad decimum, dico et pronuntio quod, quamvis secundum iura, tam canonica quam civilia, ordinationes laycorum non licent clericos, etiam si eorum concernerent utilitatem, tamen si fiant auctoritate et decreto reverendissimi domini archiepiscopi aut suorum officialium, tunc valeant et in hoc casu homines ville de Vallibus in perequationibus et estimis inde de bonis fiendis habeant convocare unum vel duos clericos dicte comunitatis ne aliqualis suspitio inter eos generetur. 
Ad undecimum, dico quod videantur instrumenta contractus emptionum et venditionum, et secundum pacta et conventiones ibidem apositas indicentur.

Super enim duodecimo dubio, dico quod, attento in sententia arbitrali de dicto bacino pauperum neque de aliis non fit mentio aliqualis et res inter alios attalis et cetera, idcirco declaro dictos bacinos teneri et eisdem observari usque nunc est fieri assuetum et pretextu sententie arbitralis in aliquo non gravari rationibus desuper expressatis.

Ad tertium decimum dubium, dico quod, attenta regula iure dicentis quod qui sentit comodum sentire debet etiam onus, et venerabiles presbiteri de dictis capitalibus fructus inde recipiant et per consequens comodum ad ipsos dignoscitur spectare, quod de fructibus inde perceptis solvant honera antedicta.

Item, super quarto decimo dubiis, dico quod iam supra fuit satisfactum tam in sententia per honorabilem dominum officialem lata quam in presenti, videlicet, quod, si dictum onzè fuit impositum pro oneribus in dicta sententia arbitrali apositis ad que presbiteri tenentur, quod tunc teneantur et obligati existant ad dictum undecimum, pro aliis vero oneribus non ${ }^{14}$.

Super quinto decimo, duco declarandum quod, si predicta quantitas venit tota in ecclesie operibus convertenda, quod clerici teneantur secundum modum et formam desuper specificatos.

Ad sextum decimum et ultimum dubium, dico quod, si super hoc est aliud statutum, usus seu consuetudo inter eos antiquata qualiter satisfactio sit fienda illis quo sunt deputati ad perequationes et estimas faciendas, quod ille usus usque actenus observatus manuteneatur in sui forma; aliud, si nullus erat usus seu consuetudo et dicti presbiteri sunt solum ad faciendum estimas de bonis clericorum, quod eo casu per comunitatem presbiterorum eis satisfiat sine autem ipsi presbiteri ${ }^{15}$ [segueix una part il.legible] ...non solum ad perequandum et estimandum bona clericorum sed etiam in aliis perequationibus seu estimis bonorum et rerum hominum ville de Vallibus uno et simul cum aliis perequatoribus electis per universitatem dicte ville, quod tunc satisfiat eis de comuni sicuti et ceteris.

Et hanc declarationem facio super dubiis inde motis et in quantum presens declaratio sapit absolutionem unam partem alteri absolvo; in quantum vero condempnationem unam partem alteri condempno.

Lata, lecta et publicata ac in scriptis recitata fuit hac sententia per dictum dominum iudicem seu comissarium pro tribunali sedente in consistorio castri archiepiscopalis Terracone, die veneris, hora completori, tricesima aprilis anno a

\footnotetext{
${ }^{14}$ Les remissions als punts de la sentència són segons l'ordre que figura en el pergamí núm. 203, de manera que el punt 14è correspon al 15è de les apel-lacions i el 15è al 14è. aquí.

${ }^{15} \mathrm{~A}$ la còpia que figura al registre de la cort del batlle. el text d'aquest parràgraf finalitza
} 
Nativitate Domini millesimo trecentesimo nonagesimo quinto, presentibus et petentibus discretis Raymundo Virgili, procuratore comunitatis dictorum presbiterorum, et Petro Brugar, procuratore universitatis dicte ville de Vallibus, ex altera, et presentibus testibus ad hec specialiter vocatis et rogatis venerabilis et discretis Marcho Patau, iureperito, Johanne Aznar, Anthonio Tost, scriptore, Laurentio Arboçar, sutore, civibus Terracone, et pluribus aliis, et Johanne de Virgilio, notario curie officialatus Terracone.

\section{RESUMÉ}

On offre ici un étude des cas, tout analysant, dans une localité comme c'était Valls (Camp de Tarragona), les controversies et problèmes fiscales posées pendant le XIV“ siècle entre la municipalité et certain collectif -celle des clercs-, à partir des accords pris, et aussi à partir des sentences promulguées, entre ce collectif et les répresentants municipales, ce qui permet connaître assez bien, dans ce cas, quelle était la situation des personnes ecclésiastiques devant l'impôt -à niveau générale - et le processus de formation de leur régime físcal -à niveau plus particulier-. On peut observer de façon très détaillée toutes les obligations fiscales lesquels pesaient sur les membres de ce collectif, même la forme d'être taxés ainsi comme la taux de participation aux impôts municipales, tout ce qui conformait un status fiscal différentiel -et assez avantageuse- en opposition avec les autres contribuables locales.

\section{SUMMARY}

This article presents an analytical case study of the fiscal controversies which arose in Valls (Camp de Tarragona) during the fourteenth century relating to controversies between the municipal officers and the collective of the town's clergy - processes which afford an intimate view both at the general level, of the position of ecclesiastical officials before the imposition of tax, and at the particular level. of the process of formation of the town's financial administration. Thus one observes in great detail various fiscal obligations (both in manner and form of the municipal taxes they paid) which were required of this collective. In sum, it can be seen that, to their great advantage, they enjoyed a fiscal status distinct from that of other contributors. 